\title{
The environmental features of the Monte Corchia cave system (Apuan Alps, central Italy) and their effects on speleothem growth
}

\author{
Piccini L. ${ }^{1}$, Zanchetta G. ${ }^{2,8}$, Drysdale R.N. ${ }^{3}$, Hellstrom J. ${ }^{4}$, Isola I. ${ }^{5}$, Fallick A.E. ${ }^{6}$, \\ Leone G. ${ }^{7}$, Doveri M. ${ }^{8}$, Mussi M. ${ }^{8}$, Mantelli F. ${ }^{9}$, Molli G. ${ }^{2}$, Lotti L. ${ }^{10}$, Roncioni A. ${ }^{11}$, \\ Regattieri E. ${ }^{11}$, Meccheri M. ${ }^{12}$, Vaselli L. ${ }^{13}$
}

\begin{abstract}
:
Piccini L., Zanchetta G., Drysdale R.N., Hellstrom J., Isola I., Fallick A.E., Leone G., Doveri M., Mussi M., Mantelli F., Molli G., Lotti L., Roncioni A., Regattieri E., Meccheri M. and Vaselli L. 2008. The environmental features of the Monte Corchia cave system (Apuan Alps, Central Italy) and their effects on speleothem growth. International Journal of Speleology, 37(3), 153-172. Bologna (Italy). ISSN $0392-6672$.

The Monte Corchia cave system, one of the most famous and popular caves in Italy, has in recent times been the subject of investigation on its speleothems as paleoclimate archives. This paper describes the geology, geomorphology and water chemistry of the cave system with the aim to elucidate the processes that have generated these speleothems and the properties they contain that are so useful for paleoclimatology. Some general conclusions can be drawn: i) the Corchia system is a cave developed over different altitudes during progressive uplift of the mountain chain in which it is located, probably under drainage conditions very different to those of the present. This has allowed the development of a large (ca. $60 \mathrm{~km})$ and deep (-1187 $\mathrm{m}$ ) karst system; ii) the dewatering phases have left the deepest chambers far away from clastic input and with long drip pathways; iii) the peculiar geological context has permitted the water to intercept and dissolve a significant source of $U$ (still unknown) that facilitates radiometric dating; iv) in the last $1 \mathrm{Ma}$ at least, no significant changes have occurred in the relief and in the epikarst, in the sense that speleothems have grown under very similar conditions. In addition the extremely low Ca concentration of drip waters have permitted low speleothem growth rates and, at least for the "Galleria delle Stalattiti", the zone under paleoclimate studies, a stable plumbing system (i.e. chemistry and stable isotopes of drip waters) has produced calcite close to isotopic equilibrium.
\end{abstract}

Keywords: speleothems, karst geomorphology, cave water chemistry, Corchia cave system, Apuan Alps, Central Italy.

Received 12 February 2008; Revised 23 July 2008; Accepted 28 July 2008

\section{INTRODUCTION}

Discovered on 11 October 1840 by Emilio Simi, a local naturalist, the Monte Corchia cave system has long been one of the most famous and popular caves of Italy. Initial surveying of the cave dates to the second half of the $19^{\text {th }}$ century, but serious exploration began only at the beginning of the $20^{\text {th }}$ century. In 1934 , cavers from Florence attained what they believed to be the bottom of the cave, at about $540 \mathrm{~m}$ below the entrance, the

1 Dipartimento di Scienze della Terra, University of Firenze,

Via la Pira 4, 50121 Firenze, Italy.

E.mail: leonardo.piccini@unifi.it.

2 Dipartimento di Scienze della Terra, University of Pisa, Via S. Maria 53, 56126 Pisa, Italy.

3 School of Environmental and Life Sciences, University of Newcastle, Callaghan, NSW 2308, Australia.

4 School of Earth Sciences, University of Melbourne, Parkville, Victoria 3010, Australia.

5 Istituto Nazionale di Geofisica e Vulcanologia, Sez. di Pisa

Via della Faggiola, 32, 56100 Pisa.

6 Scottish Universities Environmental Research Centre, East Kilbride, Scotland. deepest in the world at that time. In the second half of the last century, thanks to its relevant development and depth, the Monte Corchia Cave attracted hundreds of speleologists from Italy and abroad. In the 1980s the collaboration and, at times, the competition among several Italian caving groups allowed the exploration of about $60 \mathrm{~km}$ of cave passages, thanks to the connection of different caves belonging to the same karst system, with the depth reaching $1187 \mathrm{~m}$.

7 Dipartimento dell'Uomo e dell'Ambiente, University of Pisa, Via delle Belle Torri 18, 56127 Pisa.

8 Istituto di Geoscienze e Georisorse, Area della Ricerca CNR di Pisa, Via G. Moruzzi 1, 56124 Pisa.

9 Agenzia Regionale per la protezione Ambientale della Toscana (ARPAT) - Dipartimento Provinciale di Firenze.

10 Agenzia Regionale per la protezione Ambientale della

Toscana (ARPAT) - Dipartimento Provinciale di Massa.

11 Gruppo Speleologico Lucchese, Lucca Italy.

12 Dipartimento di Scienze della Terra, University of Siena, via Laterina 8, I-53100 Siena, Italy

13 Istituto di Geoscienze e Georisorse, UO Pisa, Via S. Maria 53, I-56126 Pisa Italy. 
The Monte Corchia massif, which hosts the entire cave complex, is a site of historical and modern marble exploitation. It is part of the vast district of the Alpi Apuane, which has yielded some of the most famous ornamental marbles in the world. Marble exploitation, speleological activity and cave preservation have never quite found a complete equilibrium.

In the recent past (1985), the area of Monte Corchia has been included in the Alpi Apuane Regional Park and on 4 August 2001 part of the cave system was opened to the public after three years of construction work. The opening of the tourist cave has not completely cooled the struggles between the defenders of this natural heritage and "the quarrymen", but it has shown that local economic benefits can arise from using this landscape without the need to extract marble.

The Federazione Speleologica Toscana (Tuscan Speleological Federation) understood the new potential of easier accessibility to the cave, and has logistically and economically supported (since 1998) palaeoclimate research using speleothems. The ongoing research has demonstrated that a new scientific "adventure" has now begun (e.g. Drysdale et al., 2004, 2005, 2007; Zanchetta et al., 2005, 2007).

The potential of this cave for paleoclimatological studies is huge. Data so far obtained suggest that it would be possible to obtain a continuous record as far back as 1,5 Ma from stalagmites and flowstones (e.g. Woodhead et al., 2006) using U/Th, U/U and $\mathrm{U} / \mathrm{Pb}$ systematics. The stalagmites so far studied have preserved in their oxygen isotope composition a detailed record of past climatic changes, which mimics the sea-surface temperature over the Western Mediterranean and North Atlantic (Drysdale et al., 2004, 2005, 2007).

The $\delta^{18} \mathrm{O}$ values of calcite usually increase during colder periods and decrease during warmer and wetter phases, probably due to the effects of changes in precipitation amount (the so called "amount effect"). Growth rate is an additional climate proxy for these speleothems in its own right (Drysdale et al., 2007), mirroring $\delta^{18} \mathrm{O}$ time series. The $\delta^{13} \mathrm{C}$ of Corchia speleothems seems to record climatic perturbations superimposed over soil evolution above the caves, usually correlating positively with $\delta^{18} \mathrm{O}$ during cold excursions. During the transition from a glacial to an interglacial, there is an interesting lag observable, probably due to delay in soil development over very rugged and steep relief.

This paper is a collation of the works conducted by many specialists who are currently working on this cave system from several points of view. In the last years the study of Corchia speleothems has brought together scientists from different fields, and this paper represents the first holistic contribution on the cave and its environment and explains why it preserves such relevant records of past climate changes.

\section{GEOGRAPHICAL AND GEOLOGICAL FRAMEWORK}

\section{Location and geographic framework}

Monte Corchia is located in the south-western part of the Alpi Apuane (NW Tuscany, Italy), a mainly calcareous mountain range about $50 \mathrm{~km}$ long, 20 $\mathrm{km}$ wide and up to $1947 \mathrm{~m}$ high (Fig. 1). The alpinelike landscape of this peculiar region is due to several factors. In particular, the complex structural setting, characterized by very steep bedding and the tectonic repetition of different rocks (mainly limestone and phyllite), has enhanced the role of differential erosion.

The present topography is presumed to be the result of heavy fluvial erosion accompanied by rapid tectonic uplift during the Early Pleistocene (Piccini et al., 2003; Bartolini, 2003). Glacial and periglacial processes reshaped the landscape mainly during the last two glacial stages, emphasising the "alpine-like" features of this mountain range (Braschi et al., 1986).

A large part of the Alpi Apuane consists of carbonate rocks. Despite this, only a few large-scale karst landforms occur, while medium and small-scale landforms are widely represented. The present effects of karst processes on the landscape are limited, since the high relief enhances the role of physical degradation by running waters and cryogenic processes along the higher ridges. On the contrary, in the past a subdued relief has permitted the development of a more advanced exokarst and of large cave systems; therefore, most of the major karst landforms and caves are relict forms (Piccini, 1998).

\section{Local climate}

The Alpi Apuane is one of the rainiest areas in Europe. Mean annual rainfall exceeds $2500 \mathrm{~mm}$ over a large part of the chain and on the central ridges it is more than $3000 \mathrm{~mm} / \mathrm{yr}$ (Rapetti \& Vittorini, 1994; Piccini et al., 1999). The Corchia area is surrounded by six official meteorological stations, located at the villages of Retignano, Terrinca, La Polla, Campagrina, Isola Santa and Fornovolasco (Fig. 1). Table 1 shows the long-term mean precipitation in these localities; Campagrina, very close to Monte Corchia, has a mean annual precipitation of $3055 \mathrm{~mm}$, one of the highest values in Italy.

Monte Corchia is part of the main drainage divide, which separates rivers flowing to the coastline of Mar Ligure from those flowing to the interior basin

\begin{tabular}{|c|c|c|}
\hline Station & $\begin{array}{c}\text { Elevation } \\
\text { (m a.s.l.) }\end{array}$ & $\begin{array}{c}\text { Mean rainfall } \\
\text { (mm/yr - 1951-2000) }\end{array}$ \\
\hline Terrinca & 485 & 1830 \\
\hline Retignano & 440 & 1910 \\
\hline La Polla & 600 & 2240 \\
\hline Campagrina & 850 & 3055 \\
\hline Isola Santa & 585 & 2620 \\
\hline Fornovolasco & 470 & 2395 \\
\hline
\end{tabular}

Table 1 - Mean annual precipitation in the meteorological stations nearby the Mt. Corchia. 


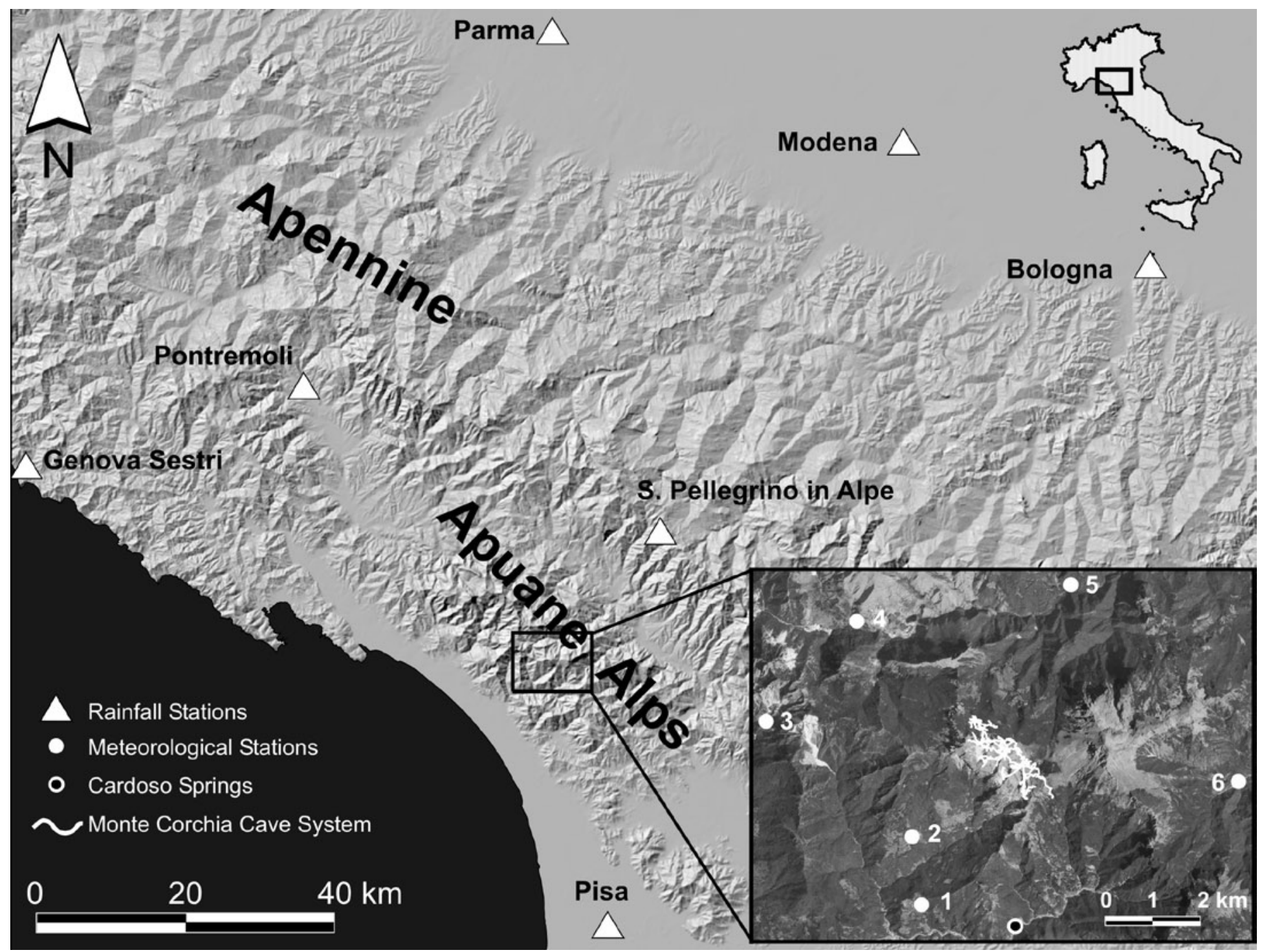

Fig.1. Location map of the studies area. Rainfall station lower panel: 1) Retignano; 2) Terrinca; 3) La Polla; 4) Campagrina; 5) Isola Santa and 6) Fornovolasco.

of the Serchio River. For this reason, its climate is characterized by variations as a function of elevation and distance from the sea.

Although rain usually increases with altitude, the rainfall registered by stations located in the most entrenched valley and just beyond the mountain crests, such as Campagrina, Isola Santa and Fornovolasco, can be considered as representative of an upper elevation.

According to Piccini et al. (1999), the mean precipitation in the whole hydrogeologic system of Monte Corchia is $2650 \mathrm{~mm} / \mathrm{yr}$ (based on data from 1951 to 1995$)$, while infiltration, calculated using the Thorntwaite method and assuming a mean infiltration rate of $55 \%$, is estimated at ca. $1150 \mathrm{~mm} / \mathrm{yr}$. In the upper area of Monte Corchia, where the cave system is located, the mean annual rainfall is around 3000 $\mathrm{mm}$, with an effective infiltration of ca. 1500-1600 $\mathrm{mm} / \mathrm{yr}$.

Regional rainfall is concentrated in autumn and spring, but a real dry period does not occur. An estimation of annual distribution of infiltration has to take into account of the fact that in winter most of the precipitation occurs as snow, which persists until March-April. For this reason infiltration is concentrated during two periods: the early spring, when melt water adds to rainfall, and the autumn, the most rainy period, when temperatures are low enough to reduce evaporation and the trees have already lost their leaves, reducing the amount of interception by vegetation.

Fig. 2 shows the precipitation at $1000 \mathrm{~m}$ on Monte Corchia obtained with the mathematical expression proposed by Piccini et al. (1999), compared with infiltration estimated by taking into account the accumulation of snow during winter and its melting during the spring season based on mean daily temperatures. The proposed altitude is roughly the average of that where infiltration feeds the cave system.

Mean temperatures are difficult to estimate because of the lack of long-term meteorological monitoring in the high-altitude zones. The only thermometric station is at Retignano, which is located at $440 \mathrm{~m}$ a.s.1. on the southern side of the mountain and so it cannot be considered representative of the whole area. Air temperatures measured in two stations installed by Azienda Regionale Protezione Ambiente Toscana (ARPAT) supply the values reported in table 2, which refer to the year 2002 .

It is probable that the cave itself provides the best estimate of mean annual temperature of the 


\begin{tabular}{|c|c|c|c|c|}
\hline $\begin{array}{c}\text { Meteorological } \\
\text { Station (ARPAT) }\end{array}$ & $\begin{array}{c}\text { Mean Air Temperature } \\
\left({ }^{\circ} \mathbf{C} \pm \mathbf{1} \boldsymbol{\sigma}\right)\end{array}$ & $\begin{array}{c}\text { Elevation } \\
(\mathbf{m} \text { a.s. I.) }\end{array}$ & $\begin{array}{c}\text { Mean airspeed } \\
\left(\mathbf{m ~ s}^{-1} \pm \mathbf{1} \mathbf{)}\right)\end{array}$ & $\begin{array}{c}\mathbf{N}^{\circ} \text { of hourly } \\
\text { measurements } \\
\text { considered }\end{array}$ \\
\hline Tourist entrance & $11.8 \pm 6.9$ & 860 & $0.8 \pm 0.8$ & 78420 \\
\hline Mt. Corchia crest & $7.8 \pm 7.2$ & 1480 & $2.1 \pm 1.7$ & 13880 \\
\hline
\end{tabular}

Table 2 - Mean values of air temperature and wind speed, recorded in two meteorological stations located on Mt. Corchia (for the location see Fig. 5). Data refer to 2002 onward.

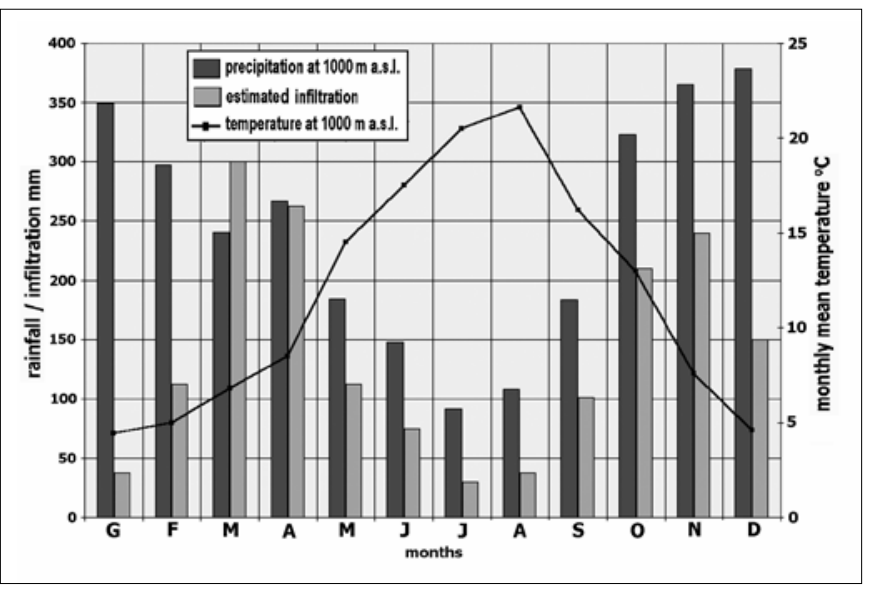

Fig. 2. Graph showing monthly temperature, rainfall and estimated infiltration on Mt. Corchia area.

mountain area. According to the temperatures registered during the cave monitoring (table 3) and taking into account the fact that mountain caves temperatures are commonly depleted by cold infiltration waters, the mean annual temperature at $1000 \mathrm{~m}$ a.s.1. should be ca. $7-8{ }^{\circ} \mathrm{C}$ in the north facing sides and ca. $8-9{ }^{\circ} \mathrm{C}$ in the southward sides.

\section{Geology}

The Alpi Apuane represents a tectonic window that shows the deepest exposed levels (Tuscan Metamorphic Units) of the Northern Apennines. The Northern Apennines are formed by a pile of tectonic units derived from the distal part of the Adriatic continental margin (Tuscan Domain) lying below the westerly-derived "oceanic" Ligurian and sub-Ligurian accretionary wedge units (e.g. Elter, 1975; Carmignani \& Kligfield, 1990; Molli \& Vaselli, 2006 and references therein).

Two major tectono-metamorphic units are traditionally distinguished in the Alpi Apuane region: the Massa unit and the Apuane unit. A Palaeozoic basement with a Mid-Triassic succession and the higher-grade peak metamorphic assemblages, kyanite+chlorithoid in metapelites (references in Molli \& Vaselli, 2006) characterize the Massa unit, which is well exposed in the westernmost part of the Alpi Apuane.

On the contrary, the Apuane unit shows a lithostratigraphic sequence made up of a Palaeozoic basement (mainly phyllites and metavolcanics) unconformably overlain by a well-developed Upper Triassic-Oligocene metasedimentary succession. The Mesozoic cover includes Triassic continental to shallow water deposits ("Verrucano") followed by Upper TriassicLiassic carbonate platform metasediments comprising dolostones ("Grezzoni"), dolomitic marbles and marbles (the famous "Carrara marbles"), which are followed by Upper Liassic-Lower Cretaceous cherty metalimestones, cherts and calcschists. Lower Cretaceous to Lower Oligocene sericitic phyllites and calcschists, with marble interlayers, are related to deep-water sedimentation during drowning of the former carbonate platform. The Oligocene-Early Miocene (?) sedimentation of turbiditic metasandstones ("Pseudomacigno") closes the sedimentary history of the domain.

The Alpi Apuane deformation structures are interpreted as formed by two main tectono-metamorphic regional events (D1 and D2 phases of Carmignani \& Kligfield, 1990), which are regarded as a progressive deformation of the inner Northern Apennine continental margin during collision and late to post-collision evolution (e.g. Molli \& Meccheri, 2000; Molli \& Vaselli, 2006). During $\mathrm{D} 1, \mathrm{SW}$ to NE directed overthrusts and NE-facing tight to isoclinal recumbent folds with flat-lying axial surfaces were produced during deformation in mid-crustal conditions. In the following D2 history previously formed structures were refolded and the present-day geometry of the tectonic units and structures was achieved. In the early stage of D2, folds associated with sub-horizontal crenulation axial foliation were formed, whereas later deformation was associated with semi-brittle and brittle structures, represented by kink and open folds, lowand high-angle faults (Molli \& Meccheri, 2000; Ottria \& Molli, 2000).

According to available P-T data (Molli \& Vaselli, 2006 and references therein), peak metamorphism (temperature around $450-350{ }^{\circ} \mathrm{C}$ and pressure of 0.8 $0.6 \mathrm{GPa}$ ) and early deformation D1 were realized at 27-20 Ma (Kligfield et al., 1986), while early stages of $\mathrm{D} 2$, developed at $\mathrm{T}$ higher than $250^{\circ} \mathrm{C}$, predated $11 \mathrm{Ma}$ according to the zircon fission-track data of Balestrieri et al. (2003) and Fellin et al. (2004). The latest stages of deformation, accommodating vertical movements locally exceeding $4 \mathrm{~km}$, are achieved in the last $5 \mathrm{Ma}$ as constrained by low-temperature thermochronometry, which suggests the transition at $120-100{ }^{\circ} \mathrm{C}$ at between 4 and $5 \mathrm{Ma}$ in most of the metamorphic tectonic window (Abbate et al., 1994; Fellin et al., 2007 and references therein).

\section{THE KARST SYSTEM}

The geological structure of Monte Corchia is very complex and its 3D form is difficult to visualise. In any case, the karst system is well delimited, being developed inside the carbonate core of the Corchia syncline, almost completely enclosed by the nonkarstifiable, low permeability basement (Fig. 3). The presently known cave system occupies the northern 


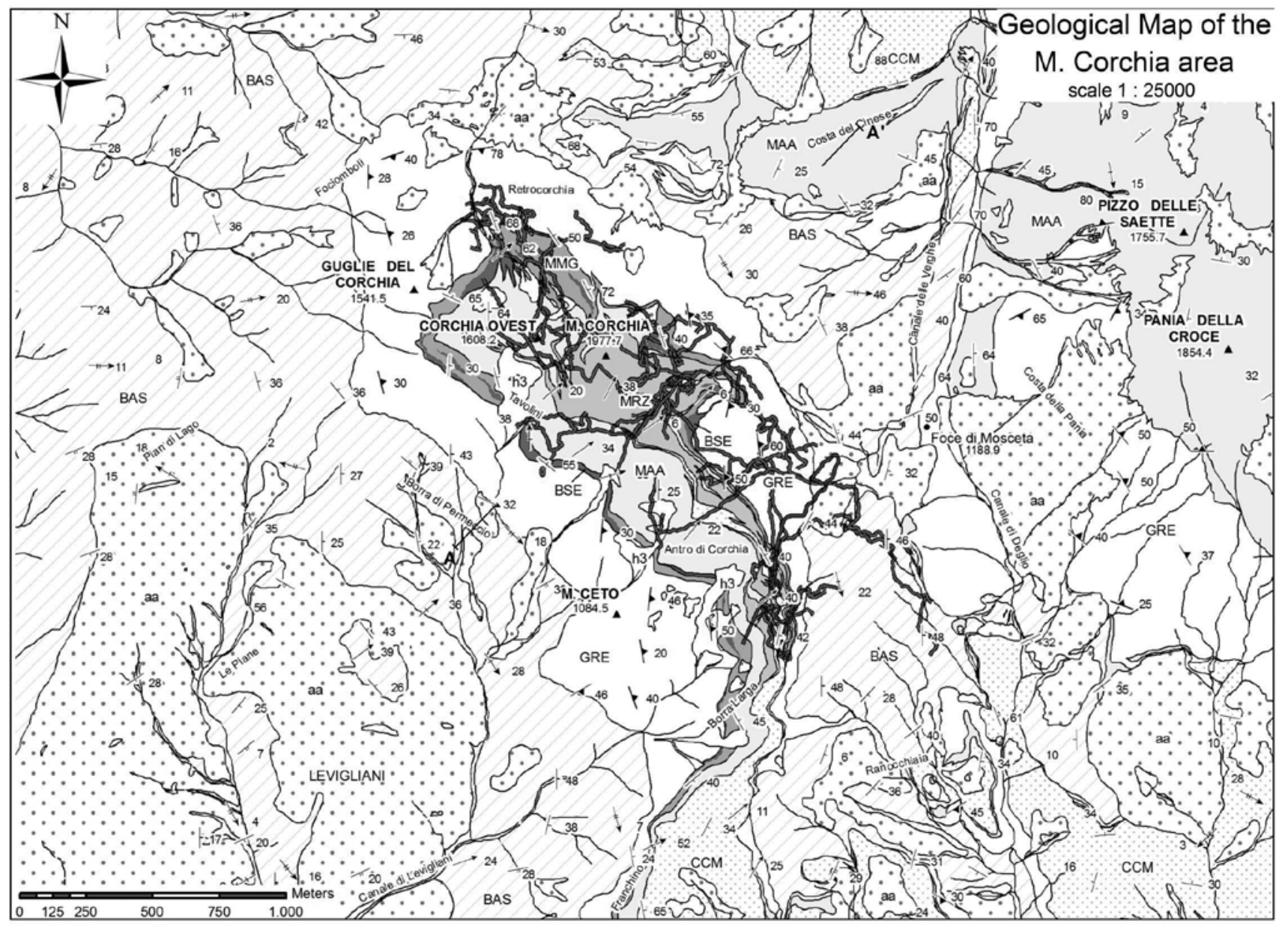

QUATERNARY DEPOSIT

\begin{tabular}{|c|c|c|c|c|c|}
\hline n3 & Quarry debris (ravaneti) & MNG & $\begin{array}{l}\text { Dolomitic marble, marble (MMG) and metabreccias } \\
\text { with chloritoid schists interlayers (BSE) }\end{array}$ & Bedding So & A1 axes \\
\hline$\because$ a & Slope debris and glacial deposits & GRE & Dolostones and Verrucano - like deposits & S1 foliation & A2 axes \\
\hline \multicolumn{2}{|c|}{ APUANE UNIT } & & Paleozoic basement & S2 foliation & Cave \\
\hline $\mathrm{ccm}$ & $\begin{array}{l}\text { Cherty limestone, calcschists with marble interlayer, } \\
\text { phyllites, metasiltites and turbiditic metasandstone }\end{array}$ & & & $\begin{array}{l}\text { L1 extension } \\
\text { lineation }\end{array}$ & \\
\hline MRZ & Marble with calcschists interlayer and metabreccias & & & & \\
\hline
\end{tabular}

MaA Marble and metabreccias

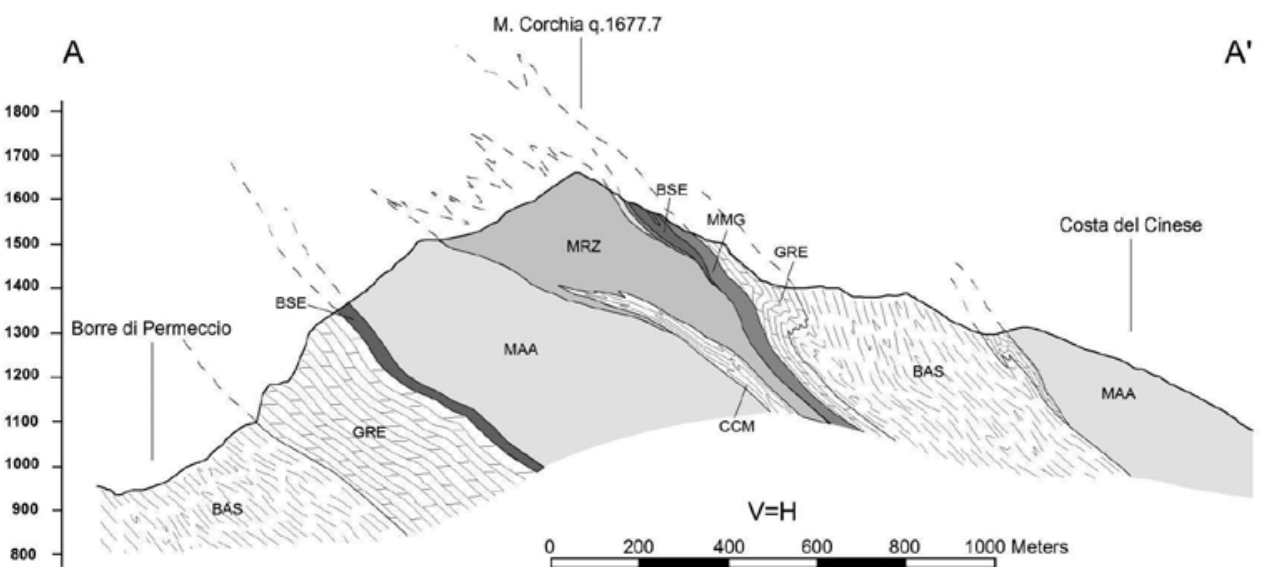

Fig.3. Geological map and cross profile of Mt. Corchia. 
part of this geological structure, while in the southern and lower sector, which corresponds to the Monte Alto ridge, there are no relevant explored caves.

\section{Geologic setting}

The geology of this area has been the subject of investigations since the late 1800s (Lotti, 1881; Zaccagna, 1932). At that time, with a simplified structural interpretation, the presence of east-dipping Mesozoic rocks between the Palaeozoic exposures (Fig. 3) was related to a west-facing overturned syncline. A similar interpretation, followed later by Maxwell (1956), was rejected by Carmignani \& Giglia (1983). According to these latter structural studies, the Corchia structure is the result of polyphase deformation during which an originally non-cylindrical eastward facing overturned syncline (D1) was refolded up to the present geometry showing the downward directed sense of younging.

The structural map and cross-section of Fig. 3 enlighten some of the major features of the geology of the Monte Corchia area. A lateral termination of the D1 syncline is well exposed in the northern part, between the Monte Corchia peak and Fociomboli, where the hinge zone of the D1 Corchia syncline is exposed. In this zone, minor $\mathrm{M}$-structures and the related axial plane greenschist foliation are refolded by open to tight east-facing D2 folds associated with a sub-horizontal crenulation cleavage. The youngest rocks in the core of the syncline are the late Jurassic cherty metalimestone in the northern part and the late Jurassic to Cretaceous calcschist, metaradiolarite, chloritic marbles and Oligocene metasandstone in the southernmost part of the map.

About 55\% of Corchia Cave is developed in Triassic dolostone and $40 \%$ in Jurassic marbles, whereas $5 \%$ of cave passages are carved in the cherty metalimestone, "Brecce di Seravezza" or dolomitic marble. The boundary between dolomite and marbles does not seem to represent an important geological horizon for the origin of the cave. Only in the northeastern sector are there passages that follow the contact between marble and dolomite.

An analysis of cave passage orientations shows that the highest and oldest level is more influenced by lithological planes, whereas the lower and youngest levels are controlled mainly by fracture patterns. This can be explained assuming that the first stage of cave development occurred when the relief was not so accentuated and the permeability of fractures was reduced by lithostatic load (Piccini, 1991).

\section{Cave geomorphology}

The Corchia cave system occupies a volume of rock about $2 \mathrm{~km}$ long, $1 \mathrm{~km}$ wide and $1 \mathrm{~km}$ high, gently dipping towards the SE. The system now has 14 entrances, the highest of which is named "Buca del Cacciatore" and opens at $1637 \mathrm{~m}$ a.s.1., just a few tens of meters below the summit of Monte Corchia. The geological structure strongly controls the pattern of the cave, which is roughly elongated according to the main axial surface, that is to say along the strike of lithological beds and main cleavage. This is true for the major conduits, which represent the main collectors, whereas the secondary branches are mostly developed along fractures oriented about N-S.

About half of the cave passages were originated under phreatic or epiphreatic conditions, in places strongly modified by vadose incision or by local breakdown. These conduits are organized as a complex 3D network distributed from 1550 to $450 \mathrm{~m}$ a.s.1., having the shape of regular tubes or canyons and with a mainly horizontal pattern (Fig. 4).

Due to percolation or vadose flows, several highgradient passages intersect the epiphreatic networks along the main fractures. These vertical caves, which show the typical features of deep alpine karst and are common features in the other areas of Alpi Apuane, are the present active drainage system from the surface to the main collector level.

The upper entrance is part of a steep canyon intercepted by surface erosion and modified by several collapses. The canyon is a relict form, probably fed by a surface basin now completely destroyed by erosion (Piccini, 1991, 1994). At $1400 \mathrm{~m}$ a.s.l. the canyon encounters a well-developed level of relict phreatic tubes, locally modified by rock falls, which develop from NW to SE, following the structural direction of main cleavage. Trending to the SE, after a SW-NE oriented, long and deep canyon, phreatic morphologies become dominant and the galleries display well-preserved sections of elliptical tubes.

The morphology of these galleries suggests a recharge by allogenic waters, which deposited conglomerates with well-rounded exotic pebbles. These pebbles consist of non-metamorphic sandstone coming from the Tuscan or Ligurian nappes, a lithology that does not outcrop in the present day cave catchment area, which thus implies a morphological setting very different from the present one (Piccini, 1991, 1998). To the SE, the level closes with a large non-penetrable rockfall. In the last part, the conduit system preserves some ancient calcite deposits, now heavily altered and mostly broken because of the gravitational collapse of the cave wall.

Different generations of high-gradient caves cut this paleo-phreatic level, many of which are active and are the present pathways of local infiltration water. More than one connection reaches a lower, almost horizontal level of phreatic tubes, which is located at an altitude of ca. 1300-1350 m. This level has a most irregular plane pattern without significant diversion. All parts of the cave system described above are completely carved in marble.

In the north-western part of the cave, one of the vadose entrenchments descends northward and reaches a second and more developed level of phreatic and epiphreatic conduits at $1200-1150 \mathrm{~m}$ a.s.l. Most of these galleries are carved in dolomite (Grezzoni). The pattern is complex, and it is often difficult to recognize the main conduits from secondary ones.

In the $\mathrm{SE}$ sector the upper system of phreatic conduits (1450-1300 $\mathrm{m}$ a.s.1.) trends gradually down along large galleries heavily modified and incised by free flow of a large quantity of water. This large canyon intersects 


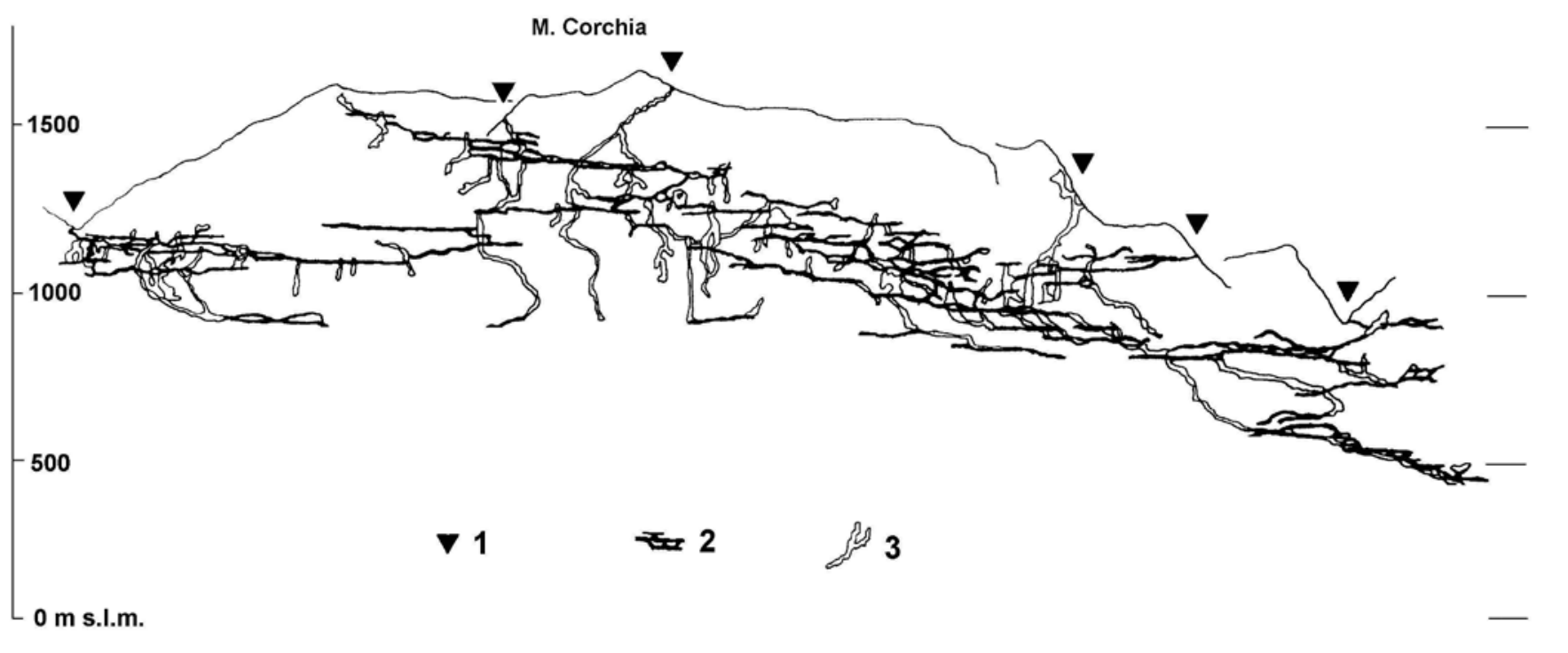

Fig.4. Sketch profile of Mt. Corchia cave system. 1) Main entrances, 2) phreatic and epiphreatic passages, 3) vadose passages.

the major phreatic level of the karst complex at 1100$1200 \mathrm{~m}$ a.s.1. This level was probably connected with the NW section to form a single and ramified system of phreatic galleries. Deep canyons entrench some of these phreatic tubes, indicating a long phase of vadose incision close to the hydrological base level. Some vadose pathways lead to a further level of phreatic conduits located about $200 \mathrm{~m}$ below, between 900 and $800 \mathrm{~m}$. The third cave level is still active in the inner part of the system, where an underground stream, whose mean discharge is presently around $0.15 \mathrm{~m}^{3} / \mathrm{s}$, flows in partially water-filled conduits. This circumstance is due to the occurrence of a structural dam that consists of low-permeability rocks ("Brecce di Serravezza" and "Scisti a Cloritoide"). Downstream of this structural obstacle the subterranean stream deepens with a long active canyon stepped by a series of waterfalls up to $40 \mathrm{~m}$ high. At an altitude of 600 $\mathrm{m}$, the stream encounters a further level of waterfilled phreatic conduits, which indicates another local perched piezometric level.

The stream flows along an unknown path, and then re-appears in the last section of the cave at $600 \mathrm{~m}$ a.s.1. The cave stream deepens towards the SE along a vadose canyon with a step-and-pool morphology until it reaches the present bottom of the cave, at $450 \mathrm{~m}$ a.s.1.

\section{The hypogean climate}

The interior climate of a complex cave system depends on several factors. In general, the temperature is mainly controlled by infiltration waters, and, secondly, by geothermal heat flux and airflow circulation (Mavlyudov, 1997; Badino, 2004). The flow of water in the vadose zone is very rapid. Consequently, the hypogean isotherms are depressed with respect to the external ones. For this reason, the temperature of cave passages far from the external surface is usually some degrees lower than the external temperature at the same elevation (e.g. compare table 2 and table 3).

Relative humidity is usually close to $100 \%$ and fluctuations are within the sensitivity of the humidity instruments employed. Airflow is present due to the numerous entrances of the system. The present number of entrances is largely unnatural because of the opening and enlargement of several entrances due to quarrying and the exploration activities of cavers. However, the elongated plan shape of some stalagmites (e.g. at the so called "Foresta Pietrificata", part of the branch called "Galleria delle Stalattiti") suggests a long period of strong airflow in ancient times. Conversely, in the more recent past, before the openings of the first artificial entrance (1841) and the enlargement of lower entrances of the cave systems by cavers (especially from 1973 to 1990), the airflow

\begin{tabular}{|c|c|c|c|c|c|}
\hline ARPAT Station & $\begin{array}{c}\text { Elevation } \\
(\mathbf{m} \text { a.s.I.) }\end{array}$ & $\begin{array}{c}\text { Mean Air Temperature } \\
\left({ }^{\circ} \mathbf{C} \mathbf{\pm} \mathbf{~} \mathbf{~}\right)\end{array}$ & $\begin{array}{c}\text { Mean humidity } \\
(\mathbf{\%} \pm \mathbf{1} \mathbf{)})\end{array}$ & $\begin{array}{c}\text { Mean air speed } \\
\left(\mathbf{m ~ s}^{-\mathbf{1}} \mathbf{\mathbf { 1 }} \mathbf{\sigma}\right)\end{array}$ & $\begin{array}{c}\mathbf{N}^{\circ} \text { of hourly measurements } \\
\mathbf{c o n s i d e r e d}\end{array}$ \\
\hline $\begin{array}{c}\text { Station 1 } \\
\text { (Galleria Franosa) }\end{array}$ & 875 & $7.4 \pm 1.2$ & $99.8 \pm 0.1$ & $0.12 \pm 0.10$ & 106539 \\
\hline $\begin{array}{c}\text { Station 2 } \\
\text { (Galleria del Venerdi) }\end{array}$ & 830 & $8.3 \pm 0.2$ & $99.9 \pm 0.1$ & $0.10 \pm 0.08$ & 98131 \\
\hline $\begin{array}{c}\text { Station 3 } \\
\text { (Galleria delle Stalattiti) }\end{array}$ & 840 & $8.4 \pm 0.3$ & $100.0 \pm 0.2$ & $0.09 \pm 0.07$ & 48500 \\
\hline
\end{tabular}

Table 3 - Mean values of air temperature, humidity and wind speed, recorded in the three stations. The data refer to the period 2002-2006, for which the data set is more complete. For station location see Fig. 5. 


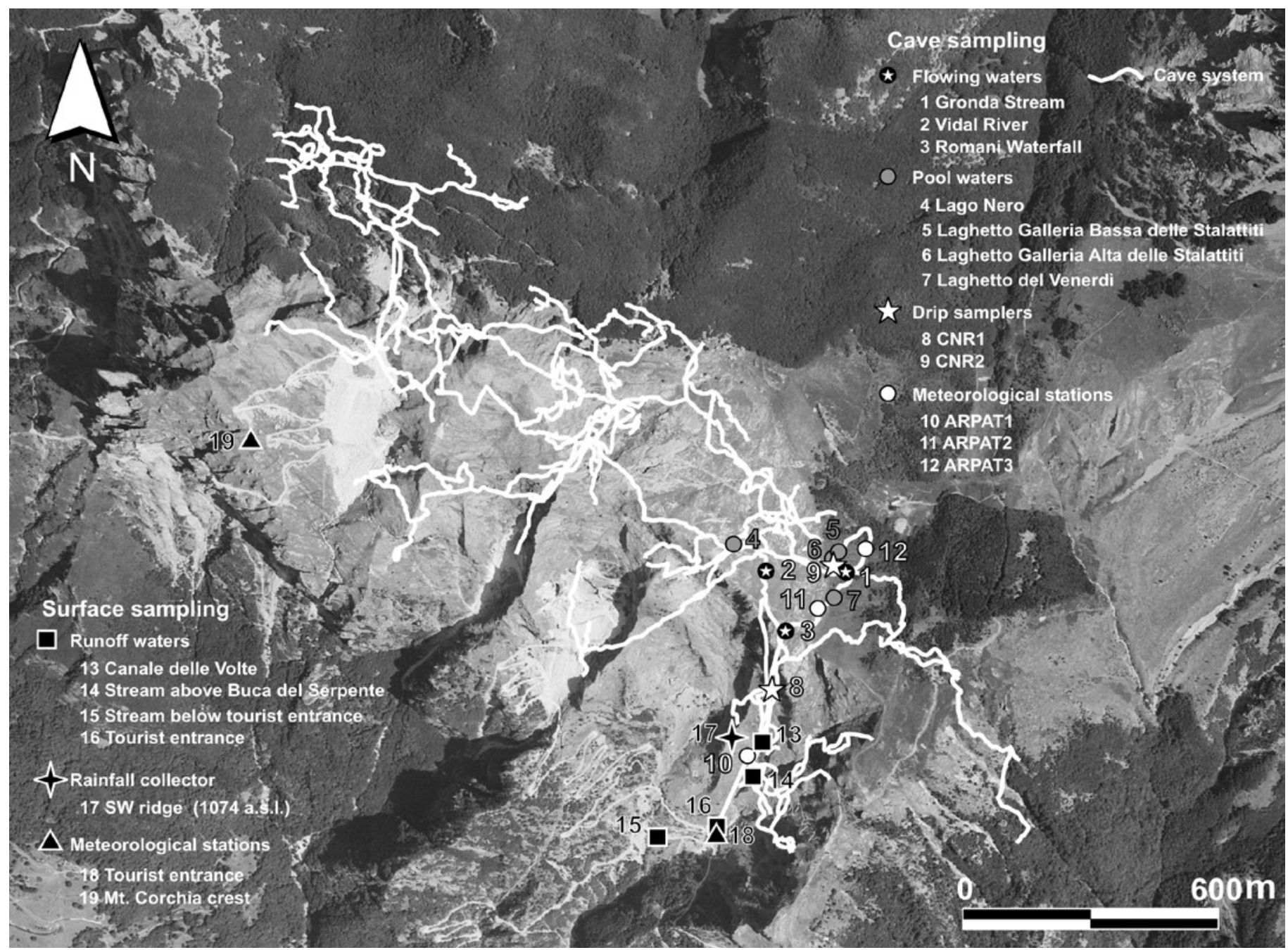

Fig. 5. Location of sampling sites on Mt. Corchia and inside the cave.

\section{SUMMER AIR FLOW}

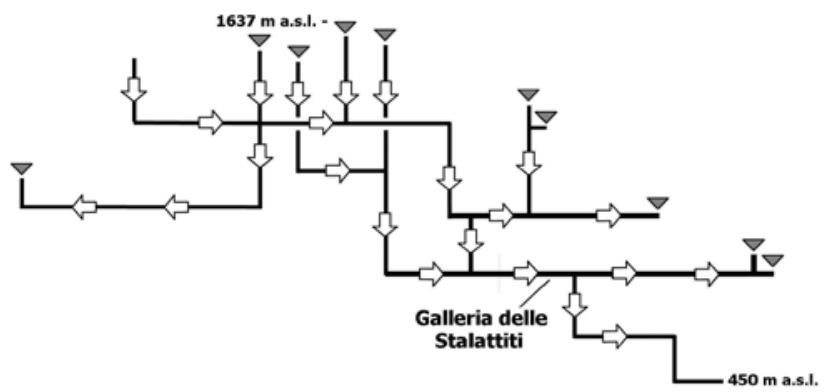

WINTER AIR FLOW

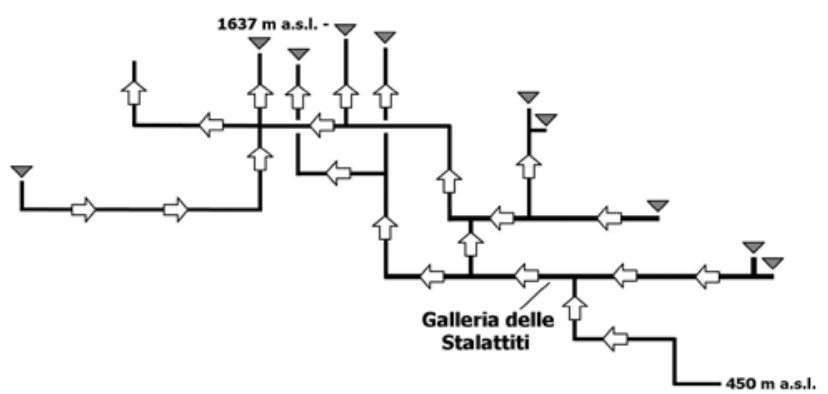

Fig. 6. Schematic airflow directions in the cave system, during winter and summer conditions, as obtained by monitoring and cavers reportages. should have been relatively low because most of the cave entrances were blocked by debris. Presently, the airflow along cave passages close to entrances (up to $200 \mathrm{~m}$ ) is influenced by external temperature and is subject to condensation or evaporation processes.

Sufficient meteorological data are available only along the tourist path where three monitoring stations of ARPAT are located (Fig. 5). This sector (about $2 \mathrm{~km}$ in length) is characterised by passages with large cross-sections. In the proximity of station 2 , mean air speed is ca. $0.10 \pm 0.08 \mathrm{~m} / \mathrm{s}$. Considering a cross section of about $50 \mathrm{~m}^{2}$ and assuming the air velocity uniform over the whole section, this corresponds to about $5 \mathrm{~m}^{3} / \mathrm{s}$ of air discharge. Fig. 6 shows the air movement over the caves obtained from monitoring and the direct observations of cavers during winter and summer circulation.

Table 3 summarizes the temperature, moisture and air velocity data at the three stations in the cave. Typical fluctuations emphasize the extreme stability of stations 2 and 3 with respect to air temperature and relative humidity, as expected for a deep sector of the cave. Note that station 1 has a mean annual temperature significantly lower than the other two due to the fact that it is located near two lower entrances through which cold air enters during winter. 


\section{General hydrology}

The hydrological structure of the Corchia karst system consists almost exclusively of the carbonate core of the Monte Corchia-Monte Alto syncline, which is cut by the Torrente Vezza. The karst area is well defined, being bordered by a belt of Palaeozoic basement. No significant allogenic recharge occurs, except for some small inputs in restricted areas on the east side of Monte Alto and in the lower part of the hydrological system. Dolomite and marbles are the main karst aquifers.

The catchment area is well constrained from dye tests performed by the Federazione Speleologica Toscana (Roncioni, 2002, and references therein). A recent experiment appears to exclude that Omo Salvatico cave, in the north of Monte Corchia, belongs to the recharge basin of Corchia system, as previously supposed on the basis of earlier dye tests (Roncioni, 2002).

The springs are located in the valley of Torrente Vezza, a few hundred meters upstream of Ponte Stazzemese, at $176 \mathrm{~m}$ a.s.1. Water rises from several points in the left side, which is the opposite side with respect to the Corchia system, of the Vezza stream, a few meters above the riverbed. Here there are several springs mantled by slope rock-fall, some perennial and some occasionally active, which together are named "Le Fontanacce", or "Cardoso" springs (Fig. 1).

A precise measure of discharge is difficult, due to the disperse outflow of this group of springs, which are distributed along the riverbed. Bibliographic sources (Piccini, 2002, and references therein) indicate discharges usually ranging from 0.06 to $0.26 \mathrm{~m}^{3} / \mathrm{s}$, with minimum values of $0.010-0.015$ $\mathrm{m}^{3} / \mathrm{s}$, but flood flows up to $3 \mathrm{~m}^{3} / \mathrm{s}$. On the basis of the few measurements available, the mean discharge is thought to be about $0.12 \mathrm{~m}^{3} / \mathrm{s}$.

The cave stream disappears at the bottom of the cave, under a rock collapse, at an altitude of 450 $\mathrm{m}$ a.s.1. and about three $\mathrm{km}$ from Cardoso springs (Fig.1). We have no information about the last part of the underground drainage, but the flow should be mainly phreatic. The elevation change from the cave bottom to the spring is probably due to the recent downcutting of surface drainage and testifies to a non-equilibrium state of the karst system with respect to the present base level (Piccini, 1998).

Piccini et al. (1999) have computed the hydrologic balance of the karst system. The surface catchment area is about $7 \mathrm{~km}^{2}$. According to these figures the mean discharge of the springs should be about 0.3 $\mathrm{m}^{3} / \mathrm{s}$, instead of $0.12 \mathrm{~m}^{3} / \mathrm{s}$. The difference is probably due to the occurrence of hidden springs along the streambed of the Vezza river.

\section{WATER GEOCHEMISTRY}

In the last ten years, several chemical analyses of rain, surface and cave waters have been performed. Most of the cave waters have been collected along the tourist path and the most visited parts of the cave, although some samples have been collected in the upper and less known sectors of the karst system (Fig. 5). Here we summarize the most relevant chemical features of waters.

\section{Rainfall and runoff waters}

Table 4 shows the mean concentration of the major ions measured in rainfall samples collected irregularly from 1997 to 2006 at a station located at $1074 \mathrm{~m}$ a.s.1. on the SW side of Monte Corchia (Mantelli et al., 2001, 2003, 2005; Fig. 1). Table 5 shows the chemistry of surface runoff collected irregularly on the $\mathrm{W}$ slopes. These waters were usually collected in ephemeral streams soon after or during significant rainfall events. Figure 7 shows a comparison between the averaged composition of local rainfall and those of surface runoff. It is obvious that the most significant ion enrichment to the runoff waters is attributed, as expected, to $\mathrm{Ca}^{2+}$ and $\mathrm{HCO}_{3}^{-}$. $\mathrm{Cl}^{-}, \mathrm{Na}^{+}$, and $\mathrm{K}^{+}$concentrations are virtually identical to that of rainfall, while the $\mathrm{SO}_{4}{ }^{2-}$ contribution from the rainfall seems to be modest.

\section{The cave waters}

\section{Flowing waters}

The general geochemistry of flowing cave waters is determined by the interaction with the host carbonate rocks, producing Ca-bicarbonate waters

\begin{tabular}{|c|c|c|}
\hline Ion & $\begin{array}{c}\text { Average } \\
(\mathbf{m g} / \mathbf{l})\end{array}$ & $\begin{array}{c}\text { Range } \\
(\mathbf{m g} / \mathbf{l})\end{array}$ \\
\hline $\mathrm{Cl}^{-}$ & 3.7 & $9.9 \div 1.0$ \\
\hline $\mathrm{NO}_{3}^{-}$ & 1.8 & $3.6 \div 0.8$ \\
\hline $\mathrm{SO}_{4}{ }^{-2}$ & 2.8 & $7.3 \div 0.2$ \\
\hline $\mathrm{HCO}_{3}{ }^{-}$ & 6.4 & $38.0 \div<5.0$ \\
\hline $\mathrm{Na}^{+}$ & 2.7 & $9.5 \div 0.3$ \\
\hline $\mathrm{K}^{+}$ & 0.4 & $4.0 \div 0.1$ \\
\hline $\mathrm{Ca}^{2+}$ & 3.0 & $9.0 \div 0.8$ \\
\hline $\mathrm{Mg}^{2+}$ & 0.4 & $2.4 \div<0.1$ \\
\hline
\end{tabular}

Table 4 - Minimum, median and maximum values of major ions in the rain water, sampled since 1997, on the SW ridge (1074 m a.s.I.) of Mt. Corchia. See Fig. 5 for the location.

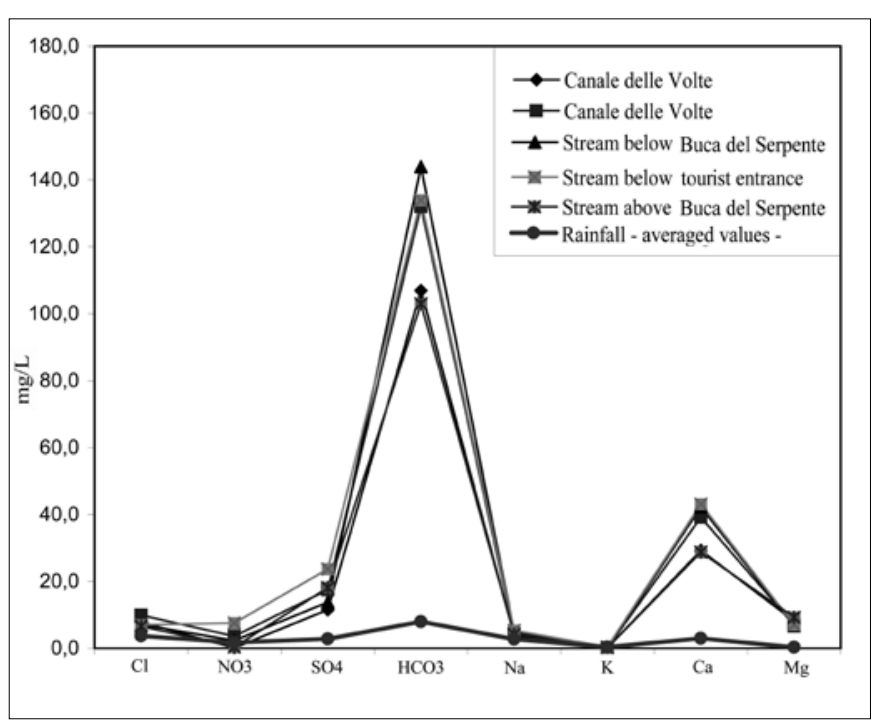

Fig.7. Comparison between the averaged composition of local rainfall and those of some superficial runoff waters. 


\begin{tabular}{|c|c|c|c|c|c|c|c|c|c|}
\hline Station & \multicolumn{2}{|c|}{ Canale delle Volte } & $\begin{array}{c}\text { Tourist } \\
\text { entrance }\end{array}$ & \multicolumn{2}{|c|}{$\begin{array}{c}\text { Stream below } \\
\text { tourist entrance }\end{array}$} & \multicolumn{4}{|c|}{$\begin{array}{c}\text { Stream above } \\
\text { Buca del Serpente }\end{array}$} \\
\hline Date & $16 / 04 / 98$ & $11 / 11 / 01$ & $16 / 04 / 98$ & $18 / 11 / 02$ & $21 / 11 / 03$ & $23 / 03 / 04$ & $12 / 12 / 04$ & $02 / 01 / 05$ & $31 / 08 / 05$ \\
\hline $\begin{array}{c}\text { Conductivity } \\
\mu \mathrm{S} / \mathrm{cm} 25{ }^{\circ} \mathrm{C}\end{array}$ & 211 & 249 & 74 & 252 & 277 & 214 & 206 & 41.4 & 181 \\
\hline $\mathrm{TDS}(\mathrm{mg} / \mathrm{l})$ & 127 & 147 & 45 & 148 & 162 & 121 & 135 & 35 & 112 \\
\hline $\mathrm{pH}$ & 8.2 & 7.8 & 8.1 & 7.8 & 7.1 & 8.0 & 7.4 & 6.6 & 7.2 \\
\hline $\mathrm{NH}_{4}{ }^{+}(\mathrm{mg} / \mathrm{l})$ & $<0.1$ & $<0.1$ & 0.1 & $<0.1$ & $<0.1$ & $<0.1$ & $<0.1$ & $<0.1$ & $<0.1$ \\
\hline $\mathrm{NO}_{2}^{-}(\mathrm{mg} / \mathrm{l})$ & $<0.05$ & $<0.05$ & $<0.05$ & $<0.05$ & $<0.05$ & $<0.05$ & 0.02 & $<0.05$ & $<0.05$ \\
\hline $\mathrm{Cl}^{-}(\mathrm{mg} / \mathrm{l})$ & 7.8 & 9.9 & 3.6 & 7.1 & 7.0 & 6.6 & 12.1 & 3.5 & 6.5 \\
\hline $\mathrm{NO}_{3}{ }^{-}(\mathrm{mg} / \mathrm{l})$ & $<0.5$ & 3.6 & 2.9 & 2.3 & 7.6 & 0.4 & 0.9 & 1.0 & 0.8 \\
\hline $\mathrm{SO}_{4}{ }^{2-}(\mathrm{mg} / \mathrm{l})$ & 11.5 & 17.5 & 9.8 & 13.8 & 23.7 & 18.1 & 15.0 & 2.4 & 19.7 \\
\hline $\mathrm{HCO}_{3}^{-}(\mathrm{mg} / \mathrm{l})$ & 107 & 132 & 27.0 & 144 & 134 & 103 & 120 & 30 & 91 \\
\hline $\mathrm{Na}^{+}(\mathrm{mg} / \mathrm{l})$ & 3.8 & 4.4 & 1.7 & 5.1 & 5.3 & 4.2 & 6.5 & 1.8 & 3.4 \\
\hline $\mathrm{K}^{+}(\mathrm{mg} / \mathrm{l})$ & 0.2 & 0.2 & 0.5 & $<0.2$ & 0.4 & $<0.2$ & 1.0 & 0.6 & 0.7 \\
\hline $\mathrm{Ca}^{2+}(\mathrm{mg} / \mathrm{l})$ & 29.3 & 39.2 & 12.5 & 42.2 & 43.1 & 28.8 & 31.9 & 10.0 & 28.6 \\
\hline $\mathrm{Mg}^{2+}(\mathrm{mg} / \mathrm{l})$ & 8.2 & 7.0 & 0.5 & 6.7 & 7.0 & 9.3 & 8.7 & 1.0 & 8.5 \\
\hline
\end{tabular}

Table 5 - Chemical analyses of running waters flowing outside the Corchia Cave system. For location see Fig. 5.

with a variable amount of $\mathrm{Mg}$, due to the presence of dolomites ("Grezzoni”) and/or dolomitic marbles (Mantelli et al., 2005). Rainfall can principally contribute $\mathrm{Cl}^{-}$and $\mathrm{Na}^{+}$from marine aerosols (Mantelli et al., 2005). Sulphate is, in some cases, close to that of rainfall but enrichment compared to rainfall values is probably related to oxidation of pyrite, a mineral phase present within the Grezzoni.

Table 6 shows a synthesis of the data obtained from the main flow of water from Cardoso Springs. A total of 108 samples were collected from 1997 to 2007. For simplicity, Table 6 shows only the maximum and minimum values measured for each sampling station. From these figures, along with the comparison of the data presented in tables 4 and 5 and Fig. 7 , it is possible to observe that mineralization of flowing waters starts soon with only a minor increase at the terminal spring.

\section{Pool waters}

Table 7 shows a synthesis of chemical analyses of three different pools discontinuously sampled since 1997 (see Fig. 5 for location). The pools of the "Galleria delle Stalattiti" and "Laghetto del Venerdi" are fed by local drips and show a virtually constant chemical composition. For this reason, table 7 shows only the average values of their chemical composition. The pools of the "Galleria delle Stalattiti" are characterised by a Ca-Mg bicarbonate composition, with a higher $\mathrm{SO}_{4}^{2-}$ content, in agreement with waters derived from contact with metadolomite, the dissolution of which releases $\mathrm{Ca}$ and $\mathrm{Mg}$, as well as the $\mathrm{SO}_{4}^{2-}$ from pyrite oxidation.

\section{Drips}

Drip water samples have been collected sporadically from different parts of the cave (especially in the area of the tourist path) but only for CNR1 and CNR2 are there enough data for a meaningful characterization (Table 8). The longest sampling period is for station CNR2. The chemistry of CNR2 drips is extremely stable and characterised by a relatively high content in $\mathrm{Mg}$ and $\mathrm{SO}_{4}{ }^{2-}$, whereas the composition of
CNR1 waters reflects contact mainly with marble.

\section{Trace elements}

Data on trace elements are few (Table 9) and concern mainly a sampling campaign carried out during 2006. Data from drip waters of CNR1 and CNR2 stations (Fig. 5) reflect sampling conducted mainly during 2003. Of particular interest is the anomaly of some elements (e.g. Ba, Mo) and, notably, $\mathrm{U}$ in the drip point of CNR2 and in the two pools of the "Galleria delle Stalattiti".

\section{Stable isotope water geochemistry}

Several rainfall stations, whose stable isotope composition is well monitored, surround the area of the Apuan Alps (Fig. 1). The data in table 10 illustrate significant differences in the average isotopic composition of rainfall as one crosses from $\mathrm{W}$ to $\mathrm{E}$ over the Apennines; about 2\%o of difference exists between stations located roughly at the same altitude. In detail, the spatial and temporal isotopic variability of local meteoric precipitation has been inferred by Mussi et al. (1998) using isotopic data obtained from non-karstic springs with small catchments, which represent a good averaging of local infiltrating water because they are unaffected by the event-scale changes in isotopic composition that can influence karstic springs. These data have been partially corroborated by results of analyses of rainfall collected at the S. Pellegrino in Alpe station (Fig. 1). Mussi et al. (1998) have shown that the altitudinal effect is variable according to mountain aspect and they reported a pronounced $\mathrm{E}-\mathrm{W}$ isotopic difference due to the typical travel path of vapour masses producing a "rain-shadow effect" due to the Alpi Apuane and the Apennine chain.

Doveri et al. (2005) reported the isotopic composition of drip waters collected in CNR1 and CNR2 stations into Corchia Cave, highlighting the presence of two distinct sectors of the plumbing system probably characterised by different residence time, event sensitivity and recharge area. Since the publication of Doveri et al. (2005) other data have been collected on the same drip points and 
in other parts of the cave, including flowing water, pools and the terminal springs of Cardoso (Table 11). Figure 8 shows the Corchia waters plotted on a $\delta^{2} \mathrm{H}_{\mathrm{H}_{2} \mathrm{O}^{-}}$ $\mathrm{\delta}^{18} \mathrm{O}_{\mathrm{H} 2 \mathrm{O}}$ diagram. Almost all waters plot closely to the Central Mediterranean Meteoric Water Line (CMMWL), with a deuterium excess (d) of 15 (Gat \& Carmi, 1970; Longinelli \& Selmo, 2003). A few of the data points show lower $d$ values without reaching the Global Meteoric Water Line (GMWL, with a $d=10$ ). The spread of values is mainly due to CNR1 station, the drips collected at the entrance in the artificial gallery and the flowing waters (the latter collected only once in March 2005). The lower isotopic values, in particular those of the flowing waters, can be explained by infiltration of water derived from snow melting, usually characterised by lower $d$ values (Mussi et al., 1998) and, possibly, derived from higher altitude recharge areas.

Figure 9 shows the oxygen isotope composition of the drip stations CNR1 and CNR2 along with four determinations of tritium content. In detail, the data show the substantial stability of station CNR2 (mean: $-7.4 \pm 0.1$ $\%$ ) and a significantly higher variability for station CNR1 (mean: $-7.3 \pm 0.4 \%$ ). The different behaviour of the two stations is replicated by the tritium data. On the hypothesis that there is no mixing of waters of different ages, the tritium data suggest residence times of ca. 50 years for CNR2, and values consistent with precipitation occurring within the year of sampling for CNR1. The data available do not support any significant differences in the altitude of recharge (ca $0.1 \%$ on average between CNR1 and CNR2, which can locally represent less than $100 \mathrm{~m}$ ), with the values of CNR1 likely to be influenced by seasonal effects and year-to-year rainfall isotopic variability, which is averaged out in the case of CNR2.

The carbon isotope composition of the dissolved inorganic carbon (DIC) supports the notion of a different plumbing system and different residence time for the two CNR stations. The differences in the $\delta^{13} \mathrm{C}_{\mathrm{DIC}}$ between CNR1 and CNR2 can be explained by a different input of biogenic (soil) $\mathrm{CO}_{2}$ via longer residence times for CNR2 station, which enhances water-rock interaction (Clark \& Fritz, 1997), bearing in mind that local carbonate rocks have $\delta^{13} \mathrm{C}$ values ranging from 1 to $3 \%$ o (Laurenzi et al., 1982). However, the data are too few for drawing firm conclusions of the origin of $\delta^{13} \mathrm{C}$ of DIC, because soil discontinuity over the recharge area and prior calcite precipitation (Fairchild et al. 2000) can play additional role.

\section{DISCUSSION}

Several geologic and environmental features make the Monte Corchia karst system one of the most promising caves in the world for paleoclimate research. The evolution of the karst system probably includes the entire Quaternary and possibly the Late Pliocene. The age of fluvial deposits containing metamorphic pebbles in the nearby subsiding basins (Calistri, 1974) suggests an exhumation age for metamorphic carbonate rocks dating back to middle Pliocene. Therefore, karstification is likely to have commenced just after this time.

Several morphological features of the cave, along with the occurrence of exotic pebbles, comprising non-metamorphic lithologies in the most upper part of

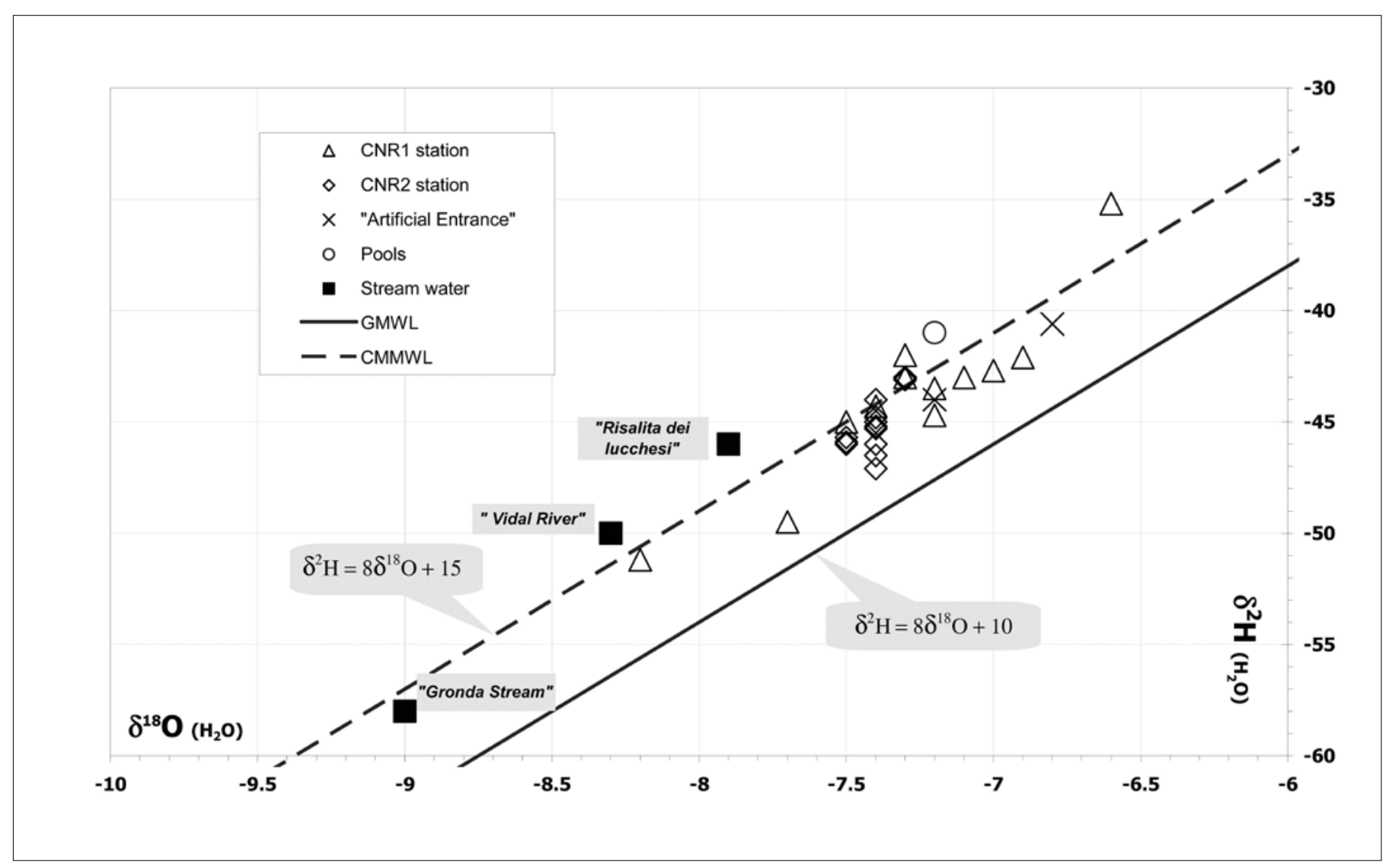

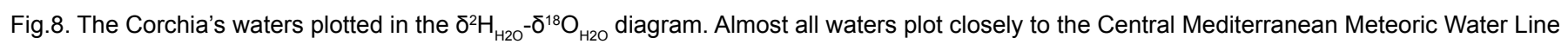
(CMMWL) with a deuterium excess (d) of 15. 


\begin{tabular}{|c|c|c|c|c|c|c|c|c|}
\hline Site & \multicolumn{2}{|c|}{ Cardoso spring } & \multicolumn{2}{|c|}{ Gronda stream } & \multicolumn{2}{|c|}{ Vidal river } & \multicolumn{2}{|c|}{ Romani waterfall } \\
\hline Sampling date & $23 / 03 / 04$ & $29 / 09 / 04$ & $05 / 09 / 01$ & $13 / 02 / 07$ & $22 / 07 / 03$ & $13 / 02 / 07$ & $14 / 05 / 98$ & $24 / 03 / 00$ \\
\hline Discharge (I/min.) & $>1000$ & 85 & 40 & 150 & 480 & 2400 & 60 & 120 \\
\hline $\mathrm{T}\left({ }^{\circ} \mathrm{C}\right)$ & 10.0 & 10.8 & 8.2 & 7.7 & 7.1 & 6.9 & 7.8 & 8.9 \\
\hline Conductivity $\left(\mu \mathrm{S} / \mathrm{cm} 25^{\circ} \mathrm{C}\right)$ & 221 & 278 & 250 & 216 & 219 & 201 & 188 & 223 \\
\hline TDS (mg/l) & 125 & 153 & 138 & 120 & 155 & 113 & 100 & 118 \\
\hline $\mathrm{pH}$ & 8.0 & 7.8 & 8.0 & 8.3 & 8.3 & 8.1 & 7.8 & 8.0 \\
\hline $\mathrm{NH}_{4}^{+}(\mathrm{mg} / \mathrm{l})$ & $<0.1$ & $<0.1$ & $<0.1$ & $<0.1$ & $<0.1$ & $<0.1$ & $<0.1$ & $<0.1$ \\
\hline $\mathrm{NO}_{2}^{-}(\mathrm{mg} / \mathrm{l})$ & $<0.05$ & $<0.05$ & $<0.05$ & $<0.05$ & $<0.05$ & $<0.05$ & $<0.05$ & $<0.05$ \\
\hline $\mathrm{F}^{-}(\mathrm{mg} / \mathrm{l})$ & $<0.1$ & 0.1 & $<0.1$ & $<0.1$ & 0.2 & $<0.1$ & $<0.1$ & $<0.1$ \\
\hline $\mathrm{Cl}^{-}(\mathrm{mg} / \mathrm{l})$ & 6.6 & 7.0 & 9.2 & 6.5 & 4.8 & 6.7 & 3.9 & 12.1 \\
\hline $\mathrm{NO}_{3}^{-}(\mathrm{mg} / \mathrm{l})$ & 1.6 & 2.7 & 1.6 & 0.8 & 1.7 & 1.1 & 2.7 & 2.6 \\
\hline $\mathrm{SO}_{4}^{2-}(\mathrm{mg} / \mathrm{l})$ & 7.4 & 18.2 & 6.6 & 3.6 & 12.5 & 4.0 & 5.3 & 6.8 \\
\hline $\mathrm{HCO}_{3}^{-}(\mathrm{mg} / \mathrm{l})$ & 126 & 138 & 141 & 129 & 121 & 116 & 98 & 107 \\
\hline $\mathrm{Na}^{+}(\mathrm{mg} / \mathrm{l})$ & 4.0 & 4.9 & 4.0 & 3.6 & 3.2 & 2.8 & 2.4 & 6.9 \\
\hline $\mathrm{K}^{+}(\mathrm{mg} / \mathrm{l})$ & $<0.5$ & 0.5 & 0.9 & $<0.3$ & 0.3 & $<0.3$ & $<0.3$ & $<0.3$ \\
\hline $\mathrm{Ca}^{2+}(\mathrm{mg} / \mathrm{l})$ & 32.4 & 38.7 & 32.3 & 27.3 & 27.4 & 30.3 & 31.6 & 30.6 \\
\hline $\mathrm{Mg}^{2+}(\mathrm{mg} / \mathrm{l})$ & 8.4 & 10.5 & 11.0 & 11.4 & 11.0 & 7.9 & 2.7 & 5.0 \\
\hline
\end{tabular}

Table 6 - Chemical composition of Corchia cave flowing waters. Only the maximum and minimum measured value is shown (see fig. 5 for location).

\begin{tabular}{|c|c|c|c|}
\hline Pool & $\begin{array}{c}\text { Galleria } \\
\text { bassa }\end{array}$ & $\begin{array}{c}\text { Galleria } \\
\text { alta }\end{array}$ & $\begin{array}{c}\text { Laghetto } \\
\text { Venerdi }\end{array}$ \\
\hline $\mathrm{N}$. of analyses & 10 & 13 & 9 \\
\hline Conductivity $\left(\mu \mathrm{S} / \mathrm{cm} 25^{\circ} \mathrm{C}\right)$ & $318 \pm 6$ & $326 \pm 8$ & $271 \pm 6$ \\
\hline $\mathrm{TDS}(\mathrm{mg} / \mathrm{l})$ & $182 \pm 6$ & $179 \pm 4$ & $142 \pm 4$ \\
\hline $\mathrm{pH}$ & $8.2 \pm 0.1$ & $8.1 \pm 0.2$ & $8.2 \pm 0.1$ \\
\hline $\mathrm{NH}_{4}{ }^{+}(\mathrm{mg} / \mathrm{l})$ & $<0.1$ & $<0.1$ & $<0.1$ \\
\hline $\mathrm{NO}_{2}{ }^{-}(\mathrm{mg} / \mathrm{l})$ & $<0.05$ & $<0.02$ & 0.05 \\
\hline $\mathrm{Cl}^{-}(\mathrm{mg} / \mathrm{l})$ & $6.0 \pm 0.5$ & $5.6 \pm 0.6$ & $6.6 \pm 0.6$ \\
\hline $\mathrm{NO}_{3}{ }^{-}(\mathrm{mg} / \mathrm{l})$ & $4.7 \pm 2.1$ & $3.3 \pm 1.9$ & $4.6 \pm 0.4$ \\
\hline $\mathrm{SO}_{4}{ }^{2-}(\mathrm{mg} / \mathrm{l})$ & $31.6 \pm 1.3$ & $35.6 \pm 1.5$ & $9.6 \pm 0.4$ \\
\hline $\mathrm{HCO}_{3}{ }^{-}(\mathrm{mg} / \mathrm{l})$ & $154 \pm 5$ & $158 \pm 10$ & $148 \pm 5$ \\
\hline $\mathrm{Na}^{+}(\mathrm{mg} / \mathrm{l})$ & $4.3 \pm 1.0$ & $4.1 \pm 0.5$ & $4.1 \pm 0.6$ \\
\hline $\mathrm{K}^{+}(\mathrm{mg} / \mathrm{l})$ & $0.9 \pm 0.7$ & $0.4 \pm 0.1$ & $0.4 \pm 0.6$ \\
\hline $\mathrm{Ca}^{2+}(\mathrm{mg} / \mathrm{l})$ & $30.3 \pm 1.0$ & $29.5 \pm 1.7$ & $28.4 \pm 1.4$ \\
\hline $\mathrm{Mg}^{2+}(\mathrm{mg} / \mathrm{l})$ & $20.6 \pm 0.9$ & $23.3 \pm 1.8$ & $15.9 \pm 1.1$ \\
\hline
\end{tabular}

Table 7 - Chemical composition of pool waters (see fig. 5 for location).

\begin{tabular}{|c|c|c|c|c|c|c|c|c|c|c|c|}
\hline \multirow{2}{*}{$\begin{array}{c}\text { Station } \\
\text { Date }\end{array}$} & \multicolumn{8}{|c|}{ CNR2 } & \multicolumn{3}{|c|}{ CNR1 } \\
\hline & $11 / 09 / 97$ & 29/11/97 & $18 / 03 / 98$ & $16 / 04 / 98$ & $20 / 06998$ & $02 / 1198$ & 29/09/99 & $17 / 11 / 04$ & 02/11/98 & $17 / 11 / 04$ & $18 / 11 / 05$ \\
\hline $\begin{array}{l}\text { Conductivity } \\
\left(\mu \mathrm{S} / \mathrm{cm} 25^{\circ} \mathrm{C}\right)\end{array}$ & 336 & 337 & 338 & 330 & 333 & 335 & 337 & 331 & 253 & 226 & 252 \\
\hline TDS (mg/l) & 191 & 192 & 193 & 198 & 199 & 201 & 184 & 190 & 152 & 132 & 144 \\
\hline $\mathrm{pH}$ & 8.1 & 8.2 & 8.2 & 8.2 & 8.2 & 8.2 & 8.1 & 7.8 & 7.9 & 8.0 & 8.1 \\
\hline $\mathrm{NH}_{4}^{+}(\mathrm{mg} / \mathrm{l})$ & $<0.1$ & $<0.1$ & $<0.1$ & $<0.1$ & $<0.1$ & $<0.1$ & $<0.1$ & $<0.1$ & $<0.1$ & $<0.1$ & $<0.1$ \\
\hline $\mathrm{NO}_{2}^{-}(\mathrm{mg} / \mathrm{l})$ & $<0.05$ & $<0.05$ & $<0.05$ & $<0.05$ & $<0.05$ & $<0.05$ & $<0.05$ & $<0.05$ & $<0.05$ & $<0.05$ & $<0.05$ \\
\hline $\mathrm{Cl}^{-}(\mathrm{mg} / \mathrm{l})$ & 5.3 & 4.7 & 4.5 & 4.8 & 4.8 & 3.9 & 5.5 & 5.4 & 5.7 & 6.9 & 6.2 \\
\hline $\mathrm{NO}_{3}^{-}(\mathrm{mg} / \mathrm{l})$ & 0.25 & $<0.5$ & $<0.5$ & $<0.5$ & $<0.5$ & $<0.5$ & 0.6 & 0.6 & 0.9 & 1.3 & 1.2 \\
\hline $\mathrm{SO}_{4}^{2-}(\mathrm{mg} / \mathrm{l})$ & 36.1 & 33.5 & 33.6 & 34.6 & 36.5 & 31.9 & 33.0 & 35.4 & 5.7 & 5.0 & 6.1 \\
\hline $\mathrm{HCO}_{3}^{-}(\mathrm{mg} / \mathrm{l})$ & 165 & 167 & 171 & 165 & 168 & 168 & 167 & 168 & 144 & 135 & 148 \\
\hline $\mathrm{Na}^{+}(\mathrm{mg} / \mathrm{l})$ & 4.3 & 4.0 & 3.5 & 3.6 & 3.9 & 3.6 & 3.6 & 3.8 & 3.5 & 3.9 & 4.2 \\
\hline $\mathrm{K}^{+}(\mathrm{mg} / \mathrm{l})$ & 0.2 & 0.3 & 0.2 & 0.3 & 0.3 & 0.2 & 0.3 & 0.3 & 0.2 & 0.2 & $<0.2$ \\
\hline $\mathrm{Ca}^{2+}(\mathrm{mg} / \mathrm{l})$ & 32.0 & 33.4 & 32.4 & 32.6 & 32.9 & 33.2 & 31.9 & 33.7 & 38.5 & 34.3 & 38.7 \\
\hline $\mathrm{Mg}^{2+}(\mathrm{mg} / \mathrm{l})$ & 22.1 & 21.7 & 21.9 & 22.2 & 21.8 & 21.4 & 22.3 & 23.0 & 7.2 & 8.3 & 8.9 \\
\hline
\end{tabular}

Table 8 - Chemical composition of drips from CNR2 station (Galleria delle Stalattiti) and CNR1 (see Fig. 5 for Location). 


\begin{tabular}{|c|c|c|c|c|c|c|c|c|c|}
\hline Sample & $\begin{array}{c}\text { Cardoso } \\
\text { spring }\end{array}$ & $\begin{array}{c}\text { Gronda } \\
\text { Stream }\end{array}$ & $\begin{array}{c}\text { Vidal } \\
\text { river }\end{array}$ & $\begin{array}{c}\text { Romani } \\
\text { waterfall }\end{array}$ & $\begin{array}{c}\text { Galleria } \\
\text { Bassa } \\
\text { Stalattiti }\end{array}$ & $\begin{array}{c}\text { Galleria } \\
\text { Alta } \\
\text { Stalattiti }\end{array}$ & $\begin{array}{c}\text { Laghetto } \\
\text { Venerdi }\end{array}$ & CNR1 & CNR2 \\
\hline $\mathrm{B}$ & 3.0 & 2.5 & 0.9 & 1.5 & 3.0 & 2.5 & 2.5 & 2.0 & 5.0 \\
\hline $\mathrm{Al}$ & 1.9 & 0.8 & 0.9 & 1.3 & 25.8 & 7.0 & 12.4 & - & - \\
\hline $\mathrm{V}$ & 0.16 & 0.21 & 0.15 & 0.11 & 0.33 & 0.15 & 0.27 & $<0.2$ & 0.38 \\
\hline $\mathrm{Cr}$ & 0.05 & 0.06 & 0.03 & 0.02 & 0.50 & 0.23 & 0.38 & 1.4 & 2.0 \\
\hline $\mathrm{Mn}$ & 0.16 & 0.10 & 0.15 & 0.64 & 0.14 & 0.12 & 0.23 & $<0.2$ & $<0.2$ \\
\hline $\mathrm{Co}$ & 0.22 & 0.16 & 0.18 & 0.19 & 0.16 & 0.15 & 0.14 & $<0.1$ & $<0.1$ \\
\hline $\mathrm{Ni}$ & 0.74 & 0.48 & 0.37 & 0.51 & 0.71 & 0.46 & 0.43 & - & 1.1 \\
\hline $\mathrm{Cu}$ & 0.13 & 0.05 & 0.02 & 0.13 & 0.12 & 0.10 & 0.32 & $<0.1$ & 0.22 \\
\hline $\mathrm{Rb}$ & 0.20 & - & - & - & - & - & - & $<0.1$ & 3.1 \\
\hline $\mathrm{Sr}$ & 78 & - & - & - & - & - & - & 20 & 55 \\
\hline $\mathrm{Mo}$ & 0.11 & 0.33 & 0.13 & 0.20 & 8.09 & 3.31 & 2.22 & $<0.2$ & 13.7 \\
\hline $\mathrm{Cd}$ & $<0.02$ & $<0.02$ & $<0.02$ & $<0.02$ & 0.07 & 0.03 & 0.02 & - & - \\
\hline $\mathrm{Ba}$ & 4.3 & 1.2 & 2.8 & 4.4 & 12.7 & 5.4 & 6.8 & 5.1 & 30 \\
\hline $\mathrm{U}$ & 0.36 & 0.55 & 0.30 & 0.13 & 7.50 & 6.09 & 1.46 & 0.04 & 7.72 \\
\hline $\mathrm{As}$ & 0.21 & 0.17 & 0.11 & 0.13 & 0.23 & 0.13 & 0.25 & - & - \\
\hline $\mathrm{Hg}$ & 0.02 & 0.01 & 0.01 & 0.01 & 0.02 & 0.01 & 0.01 & - & - \\
\hline
\end{tabular}

Table 9 - Selected trace elements composition for some Antro del Corchia waters (data are in ppb).

\begin{tabular}{|c|c|c|c|c|c|c|}
\hline Sampling station & $\begin{array}{c}\text { Elevation } \\
\text { (m a.s.I.) }\end{array}$ & $\begin{array}{c}\delta^{18} \mathrm{O} \% \\
\text { (V-SMOV) }\end{array}$ & $\begin{array}{c}\delta \mathrm{D} \% \\
\text { (V-SMOW) }\end{array}$ & d & $\begin{array}{l}\text { Sampling } \\
\text { period }\end{array}$ & References \\
\hline Pisa & 5 & -5.51 & -33.3 & 10.8 & 1993-1999 & $\begin{array}{l}\text { Longinelli \& } \\
\text { Selmo. } 2003\end{array}$ \\
\hline Pontremoli & 236 & -5.34 & -30.4 & 12.4 & $2000-2002$ & " \\
\hline Parma & 55 & -7.73 & -49.4 & 12.5 & $1995-2002$ & " \\
\hline Modena & 34 & -7.51 & -48.3 & 11.8 & $1999-2001$ & " \\
\hline Bologna & 54 & -7.50 & -48.8 & 11.3 & $1998-2001$ & " \\
\hline S. Pellegrino in Alpe & 1522 & -7.68 & -46.9 & 14.6 & 1993-1999 & " \\
\hline Genova-Sestri & 2 & -5.78 & -35.1 & 10.3 & $1961-1987$ & $\begin{array}{c}\text { Rozanski et al. } \\
1993\end{array}$ \\
\hline
\end{tabular}

Table 10 - Stable isotope composition of meteoric water around the Apuan Alps.

\begin{tabular}{|c|c|c|c|c|}
\hline $\begin{array}{l}\text { Sampling site } \\
\text { (date of sampling) }\end{array}$ & $\begin{array}{l}\delta^{13} \mathrm{C}_{\mathrm{CO}} \% \% \\
\text { DIC }^{2}\end{array}$ & TU & ${ }_{\%}^{18} \mathrm{O}_{\mathrm{H}_{2} \mathrm{O}}$ & $\underset{\% 0}{\delta^{2} \mathrm{H}_{\mathrm{H}^{2}} \mathrm{O}}$ \\
\hline CNR1 (07/06/03) & $-7.8 \pm 0.1$ & & -7.3 & -43 \\
\hline CNR1 (22/08/03) & $-7.5 \pm 0.1$ & & -7.1 & -43 \\
\hline CNR1 (13/12/03) & $-8.4 \pm 0.2$ & & -7.5 & -45 \\
\hline CNR1 (04/01/04) & & & -7.3 & -42 \\
\hline CNR 1 (17/09/04) & -6.9 & & -7.1 & -43 \\
\hline CNR 1 (16/03/05) & -6.6 & & & -49 \\
\hline CNR $1(16 / 04 / 05)$ & & & -8.2 & -51 \\
\hline CNR 1 (22/09/06) & & & -7.4 & -44 \\
\hline CNR 1 (29/09/06) & & $5.5 \pm 0.7$ & -7.2 & -44 \\
\hline CNR 1 (28/10/06) & & & $-7.7(-7.4)$ & $-49(-47)$ \\
\hline CNR 1 (26/11/06) & & & -7.2 & -43 \\
\hline CNR 1 (10/12/06) & & & -6.9 & -42 \\
\hline CNR $1(28 / 12 / 06)$ & & & -7.0 & -42 \\
\hline CNR $1(20 / 02 / 07)$ & & $4.0 \pm 0.6$ & $-6.6(-6.7)$ & $-35(-36)$ \\
\hline CNR2 (13/12/03) & $-4.0 \pm 0.2$ & & -7.4 & -46 \\
\hline CNR2 (22/08/03) & -4.2 & $2.22 \pm 0.4$ & -7.4 & -44 \\
\hline CNR2 (07/06/03) & $-4.6 \pm 0.3$ & & -7.5 & -46 \\
\hline CNR $2(17 / 09 / 04)$ & $-3.1 \pm 0.1$ & & -7.3 & -43 \\
\hline CNR $2(24 / 09 / 04)$ & $-4.4 \pm 0.1$ & $2.7 \pm 0.6$ & -7.4 & -46 \\
\hline CNR $2(16 / 04 / 05)$ & & & -7.4 & -46 \\
\hline
\end{tabular}

\begin{tabular}{|c|c|c|c|c|}
\hline CNR 2 (16/03/05) & -3.8 & & -7.4 & -43 \\
\hline CNR 2 (04/01/04) & & & -7.4 & -45 \\
\hline CNR 2 (22/09/06) & & & -7.4 & -45 \\
\hline CNR 2 (29/09/06) & & & -7.5 & -45 \\
\hline CNR 2 (28/10/06) & & & -7.4 & -47 \\
\hline CNR 2 (26/11/06) & & & -7.5 & -45 \\
\hline CNR 2 (10/12/06) & & & -7.5 & -45 \\
\hline CNR 2 (28/12/06) & & & -7.4 & -45 \\
\hline CNR 2 (20/02/07) & & & -7.4 & -44 \\
\hline Artificial entrance & & & -6.8 & -40 \\
\hline Artificial entrance & & & -7.2 & -44 \\
\hline Laghetto L 1 1(16/03/05) & -3.3 & & -7.2 & -41 \\
\hline Laghetto L 2 (16/03/05) & -4.6 & & -7.2 & -41 \\
\hline Laghetto L 1 (18/04/03) & -10.4 & & -6.9 & -39 \\
\hline Laghetto L 2 (18/04/03) & -10.1 & & -6.9 & -39 \\
\hline Cardoso spring (16/03/05) & -7.8 & & -7.4 & -45 \\
\hline Cardoso spring (13/09/05) & & & -7.1 & \\
\hline La Gronda fall (16/03/05) & -7.8 & & -9.0 & -58 \\
\hline Vidal river (16/03/2005) & -5.4 & & -8.3 & -50 \\
\hline
\end{tabular}

Table 11 - Isotopic composition of Antro del Corchia waters. CNR1 and CNR2 are drip points. 


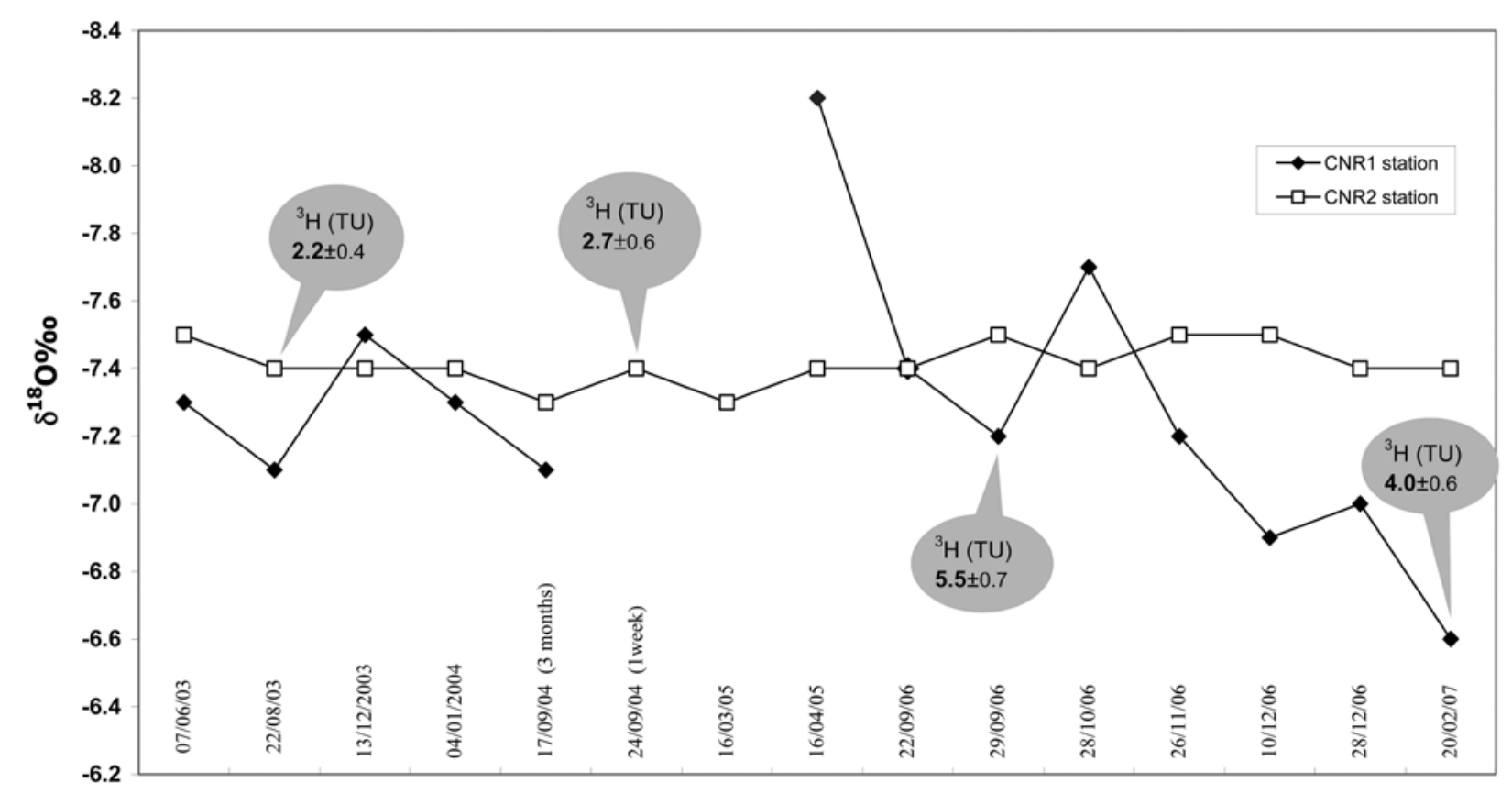

Date of collection

Fig.9. The variability of the oxygen isotope composition of the drip stations CNR1 and CNR2 along with four determination of tritium content. In detail data show the substantial stability of station CNR2 (mean: $-7.4 \pm 0.1 \%$ ) and a relatively larger variability for station CNR1 (mean: $-7.3 \pm 0.4 \%$ ).

whole evolution history of the cave system, allowing the reconstruction of the progressive dewatering stages of the karst system due to the lowering of regional base level.

Presently, the chemical and isotopic analyses have focused mainly on the "Galleria delle Stalattiti", part of the third (800-900 $\mathrm{m}$ a.s.1.) level of the cave, which is easily attainable through the tourist path. This is the sector where calcite concretions mostly occur and, therefore, where speleothem-based research was initiated.

Meteorological data indicate that this sector is relatively stable in terms of temperature, air humidity and air circulation (Table 3), in agreement with its deep position within the cave (ca. $400 \mathrm{~m}$ below the surface) and distance from natural entrances. The isotopic composition of the water ( $\mathrm{CD}, \delta^{18} \mathrm{O}$ and Tritium content) of one monitored drip (CNR 2 station, Fig. 9) indicates a stable and well-mixed plumbing system characterised by a relatively long (ca. 50 yr) residence time. Assuming this drip is representative of this sector of the cave, this implies that only persistent and relatively long-term (decadal) variations in the isotopic composition of local precipitation is capable of forcing a significant change in the isotopic composition of drip waters, and therefore the speleothem calcite. Data from other drip points, although most meaningful only for station CNR1, suggest a relationship between rock thickness above the drip points and isotopic variability. However, more drip points need to be monitored over the long term in order to prove this pattern. It is important to remember that the "Galleria delle Stalattiti" is geometrically overlain at the surface by impermeable basement of phyllites and metavolcanics, which are only superficially fractured. Furthermore, alteration processes of silicates produce clay minerals that prevent the potential for deep vertical infiltration of recharging meteoric water, obliging percolating water to take a longer travel path before reaching the chamber. This travel is partially developed along the contact zone of "Grezzoni" and this basement. The high $\mathrm{Mg}$ and $\mathrm{SO}_{4}{ }^{-2}$ content of pools and drips demonstrate the significant contribution from dolomite. The chemical composition of CNR2 station and drip-fed pools in the chamber show consistent and stable values, in agreement with the presence of a stable plumbing system as suggested by stable isotopes.

Another interesting consideration is depicted by the

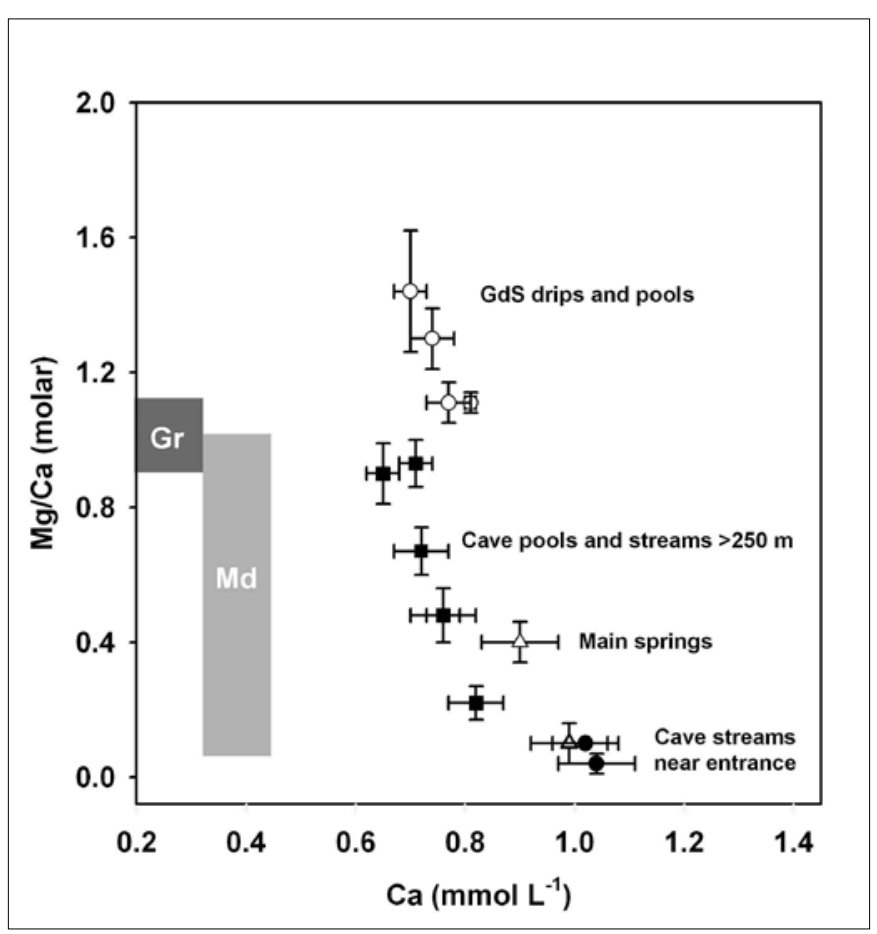

Fig. 10. Plot of Ca versus the molar ratio of $\mathrm{Mg}$ to $\mathrm{Ca}\left((\mathrm{Mg}: \mathrm{Ca})_{\text {molar }}\right)$ for various percolation waters sampled from the eastern portion of Corchia Cave. $\mathrm{Gr}=$ "Grezzoni", Md = "Marmi Dolomitici" 
chemical composition of the Corchia waters in figure 10 , which shows a plot of Ca versus the molar ratio of $\mathrm{Mg}$ to $\mathrm{Ca}\left((\mathrm{Mg}: \mathrm{Ca})_{\text {molar }}\right)$ for various percolation waters sampled from the eastern portion of Corchia Cave. Two important points can be enphasised regarding these patterns. First, the waters have extremely low $\mathrm{Ca}$ concentrations, ranging from about 0.7 to $1.1 \mathrm{mmol} / \mathrm{L}$. The similarly low values observed in the Cardoso springs, draining the Corchia catchment area, suggest that such low values are a regional phenomenon, and probably reflect the thin and highly discontinuous overlying soil cover mantling the Corchia karst, which would reduce the input of soil $\mathrm{CO}_{2}$ during percolation and therefore have a dampening effect on how much carbonate bedrock can be dissolved. Such low $\mathrm{Ca}$ values help explain the low deposition rates observed in Corchia speleothems at all time scales (Drysdale et al. 2005; Zanchetta et al. 2007). Secondly, the (Mg:Ca) molar of the percolation waters generally increases as one moves from the artificial entrance towards the "Galleria delle Stalattiti". Part of the reason for this is the transition from "Marmi Dolomitici" (dolomitic marble) to "Grezzoni" (dolomite) along this traverse. However, importantly it can also be attributed to the effects on the evolution of the percolation waters as they traverse increasing overlying bedrock thickness. Such an increase implies that waters arriving into deeper parts of the cave take a longer flow path and therefore have longer residence times within the host rock. This in turn can lead to incongruent dissolution, where the waters acquire greater quantities of $\mathrm{Mg}$ due to the different solubility of dolomite and calcite. Here, as the dolomite rock dissolves, the waters become saturated with respect to calcite but remain undersaturated with respect to the mineral dolomite. As more dolomite rock dissolves, the waters become supersaturated with respect to calcite, causing precipitation of $\mathrm{CaCO}_{3}$ and loss of $\mathrm{Ca}^{2+}$ from solution, while continuing to dissolve $\mathrm{CaMg}\left(\mathrm{CO}_{3}\right)_{2}$. This increases the $(\mathrm{Mg}: \mathrm{Ca})_{\text {molar }}$ of the percolation water. The fact that some of the "Galleria delle Stalattiti" waters exceed the $(\mathrm{Mg}: \mathrm{Ca})_{\text {molar }}$ of Grezzoni is a good evidence of this process. Prior calcite precipitation (Fairchild et al. 2000) may also be important, where calcite precipitates in air-filled voids due to $\mathrm{CO}_{2}$ degassing. This will preferentially reduce $\mathrm{Ca}^{2+}$ and leave the waters relatively enriched in $\mathrm{Mg}^{2+}$. These processes of incongruent dissolution and prior calcite precipitation both increase $(\mathrm{Mg}: \mathrm{Ca})_{\text {molar }}$ and may serve as a useful palaeohydrological proxy within the speleothems.

Although based on a few samples, some considerations can be also given about the contents of trace elements in percolation waters. Of particular relevance is the higher $U$ content of the drip water at CNR2 compared to the other analysed waters, which helps in explaining the high concentration of $\mathrm{U}$ in the speleothems collected within the "Galleria delle Stalattiti" (from ca 2 to 18 ppm, Drysdale et al., 2004, 2005, 2007; Zanchetta et al., 2007; Hellstrom unpublished data).

A possible source of the high $U$ (and other enriched trace elements) could be the small bodies of "Brecce di Seravezza", which occur occasionally at the contact between marbles and Grezzoni. These rocks are rich in heavy metals and specifically samples from Mt. Corchia show U concentrations up to ca $7 \mathrm{ppm}$ (Franceschelli et al., 1996). Our determination of $U$ concentration by alpha-spectrometry on one geological traverse of Mt Corchia (Table 12) does not show a particular U enrichment of "Brecce di Seravezza". However, based on the present position of "Brecce di Seravezza" outcrops it is not easy to imagine a significant influence on the drip water at CNR2.

The tectonic contact between basementand carbonate succession is often strongly mineralised (and in the past subject of extensive ore-deposit exploitation), and can represent an additional or alternative source of $U$ for the drip waters entering in the "Galleria delle Stalattiti". Recently, Cortecci et al. (2003) have observed that high angle brittle-fault cataclasites are strongly enriched in $\mathrm{Sr}, \mathrm{Mn}, \mathrm{Rb}, \mathrm{Cu}, \mathrm{Zn}$ and $\mathrm{Pb}$, suggesting the possibility of a different source of $U$. Indeed, a sample of these cataclasites collected on $\mathrm{Mt}$ Corchia show the highest $U$ concentration ( $>4 \mathrm{ppm})$

\begin{tabular}{|c|c|c|c|c|c|}
\hline Sample & Geology & $\underset{(p p m)}{U}$ & \pm error & $\begin{array}{l}{ }^{234} \mathrm{U} /{ }^{238} \mathrm{U} \\
\text { (activity) }\end{array}$ & \pm error \\
\hline Q1-1 & \multirow{7}{*}{ Brecce di Seravezza (Jurassic) } & 0.11 & 0.01 & 0.98 & 0.09 \\
\hline Q1-2 & & ${ }^{*} 0.07$ & -- & -- & -- \\
\hline Q1-3 & & ${ }^{*} 0.05$ &.-- & -- & -- \\
\hline Q1-4 & & 0.20 & 0.01 & 0.96 & 0.07 \\
\hline Q2-3 & & 0.33 & 0.02 & 1.01 & 0.07 \\
\hline Q2-5 & & 0.53 & 0.02 & 0.92 & 0.05 \\
\hline Q2-6 & & 0.20 & 0.01 & 1.04 & 0.06 \\
\hline Q3 & Schist (Paleozoic) & 0.87 & 0.04 & 1.23 & 0.08 \\
\hline Q4 & Schist (Paleozoic) & 0.83 & 0.04 & 1.31 & 0.09 \\
\hline Q5 & Marble (Jurassic) & ${ }^{*} 0.01$ & -- & -- & -- \\
\hline Q6 & Dolomite (Triassic) & 0.94 & 0.03 & 1.46 & 0.06 \\
\hline Q7 & Cherty limestone (Jurassic) & 0.10 & 0.01 & 1.1 & 0.1 \\
\hline Q8 & Fault cataclasite (Pliocene?) & 4.64 & 0.11 & 1.06 & 0.04 \\
\hline
\end{tabular}

Table $12-U$ concentration and ${ }^{234} \mathrm{U} / 238 \mathrm{U}$ determination of rock samples from Monte Corchia succession, as determined via alpha spectrometry: $\left.{ }^{*}\right)$ at the limit of detection of $1 \mathrm{~Bq} / \mathrm{kg}(0.1 \mathrm{ppm})$, therefore the ${ }^{234} \mathrm{U} /{ }^{238} \mathrm{U}$ activity ratio would not be reliable. 
over the collected samples. Another potential source of $\mathrm{U}$ could be represented by the basement itself, which consists mainly of phyllite and metavulcanite with presumably high $U$ content (data analysis is in progress and for some preliminary data see table 12). The progressive weathering of the palaeozoic "roof" and its progressive erosion may have produced a U-enriched residual soil, which was probably trapped in the epikarst, and then washed by seepage water. However, more prospecting is necessary to localize the exact source of $U$.

The high concentration of $U$ in the drip waters and in speleothems is accompanied by virtually absent clastic contamination of speleothems, which show $\left[{ }^{230} \mathrm{Th} /{ }^{232} \mathrm{Th}\right]_{\text {activity }}$ values $>4000$, a property, along with high $U$ content, which makes these speleothems ideal for $\mathrm{U} / \mathrm{Th}$ and $\mathrm{U} / \mathrm{Pb}$ dating (Woodhead et al., 2006), and requiring for $\mathrm{U} / \mathrm{Th}$ dating negligible correction procedures (e.g. Hellstrom, 2007).

No active stalagmite growth has been observed in the "Galleria delle Stalattiti" and in areas located adjacent to the tourist path. Four years of attempts in collecting active drip precipitates have failed at both stations CNR1 and CNR2, a fact attributed to the extremely low $\mathrm{Ca}$ concentration of the source waters (Drysdale et al., 2004) but perhaps also due to the use of a glass substrate. However, the $\delta^{18} \mathrm{O}$ composition of a theoretical calcite precipitated in the chambers should be (using the modified version of the Craig 1965 equation, e.g. Hoefs, 2004) ca. -5.6 $\%$, which is actually lower than the average $\delta^{18} \mathrm{O}$ values of two Holocene speleothems collected from the same chamber (CC4: $-5,0 \pm 0.3 \%$, n=80; CC26: $-4.4 \pm 0.2 \%$ o $n=794$, see Zanchetta et al., 2007 for CC26 analyses). Traverses performed on many speleothems of this chamber (e.g. Drysdale et al., 2004; 2007) usually respond favourably to Hendy's test (Hendy, 1971), suggesting that calcite precipitation generally occurs close to isotopic equilibrium, at least along the growth axis and taking into account the difficulty of sampling well-defined laminae in a slow growing speleothem. The discrepancy of ca. 1-0.6\%o $\mathrm{\delta}^{18} \mathrm{O}$-enrichment of Holocene speleothem calcite compared to the predicted value is within the range of offset reported $(<1 \%$ ) by the compilation of McDermott et al. (2005). This offset could be partly due, at Corchia, to the progressive opening of new entrances by quarry activity and cavers in the last decades, which may have modified air circulation even if this seems to have relatively little influence in such a deep part of the cave. A further effect can be related to changes in land use, from open woodland to grassland in an environment mostly devoted to grazing and then to marble exploitation: a case documented for nearby Alpi Apuane areas (Quiros Castillo, 2004). A similar offset is observed for the carbon isotope composition. At the measured $\mathrm{pH}$ (ca 8.2) the $\delta^{13} \mathrm{C}$ values of DIC of the drip water $(-3.9 \pm 0.6 \%$ o) should be close to the $\delta^{13} \mathrm{C}$ values of a calcite precipitated under equilibrium conditions (e.g. Clark and Fritz, 1997). The $\delta^{13} \mathrm{C}$ expected value of calcite is, however, lower than that observed in Holocene stalagmites (CC4: -2.0 $\pm 0.3 \%$;
CC26: $-1.5 \pm 0.4 \%$, with the latter excluding the values of the Early Holocene). These differences, however, are based on the assumption that station CNR2 is representative of the whole set of drips in the "Galleria delle Stalattiti" where all speleothems have been collected so far, which is probably only true as a first approximation. Different drips may have shown small different chemical and isotopic compositions as they were fed by different horizons, experienced different mixing paths and traversed different sectors of the cave.

Despite the offset, which can be produced by $\mathrm{CO}_{2}$ degassing, the high $\delta^{13} \mathrm{C}$ values are generally suggestive of low input of biogenic $\mathrm{CO}_{2}$ (Dulinski \& Rozanski, 1990), which is in agreement with the poorly developed soil cover over Corchia and in particular with the potential recharge area of the "Galleria delle Stalattiti". However, the mechanisms that are responsible today in producing low $\mathrm{Ca}$ and high $\mathrm{Mg}$ concentrations could be the same as those which produce high $\delta^{13} \mathrm{C}$ values of DIC (incongruent dissolution of dolomite with associated precipitation of calcite and prior calcite precipitation). Additional dissolution of marbles via sulphide oxidation (e.g. iron sulphide) can also play a role in increasing the isotopic composition of DIC (Spötl \& Mangini, 2007).

Recent $\mathrm{U} / \mathrm{Pb}$ and ${ }^{238} \mathrm{U} /{ }^{234} \mathrm{U}$ dating of speleothems from this chamber suggest that phreatic activity over the "Galleria delle Stalattiti" ceased prior to ca. $1 \mathrm{ka}$ (Woodhead et al., 2006 and unpublished data). Over 200 age determinations suggest almost continuous deposition over the entire middle to late Quaternary, with hiatuses occurring locally mainly during glacial maxima and/or during pronounced short cooling phases (e.g. Drysdale et al., 2004; 2005; 2007). Despite the presence of hiatuses the possibility of compiling a continuous record over the last $1 \mathrm{ka}$ is, however, realistic. There are good reasons to think that the "Galleria delle Stalattiti" did not experience dramatic changes during this period of time. The most striking evidence is represented by the almost constant values of $\delta^{13} \mathrm{C}$ through time, which varied in the last $1 \mathrm{ka}$ between a range of ca -3 and +3 per mill, with the higher values occurring during glacial and lower during interglacials (e.g. Drysdale et al., 2004). The stable carbon isotopes seem to suggest that soil never significantly contributed biogenic $\mathrm{CO}_{2}$ to the DIC pool during very old periods and that flow paths have continuously favoured a long interaction with the karst rock in a situation in which relief energy cannot have changed much, at least for the period of speleothem growth. Although the most important phase of speleothem growth predates the Holocene and is probably related to the Middle Pleistocene (Zanchetta et al., 2005), carbon isotopes do not suggest significant changes in the condition of the epikarst. The progressive decrease of growth within the "Galleria delle Stalattiti" is probably related to natural hydrological evolution and progressive senescence of flow paths. 


\section{CONCLUSION}

The "Galleria delle Stalattiti" is the sector of Corchia Cave where speleothem-based studies have been presently focused. Its accessibility and the higher number of speleothems mainly drove this focus. Monitoring of this gallery has revealed that it is fed by drips with very constant chemical and isotopic composition, which indicate a well-mixed flow, with relatively long residence time and stable conditions in terms of temperature and humidity. The speleothems have grown slowly owing to (presumably) persistently low $\mathrm{Ca}$ concentrations in the waters and slow $\mathrm{CO}_{2}$ degassing, which can be considered optimal conditions for precipitation of calcite close to isotopic equilibrium. However, this situation prevents us from obtaining paleoclimate records with sub-decadal resolution. Indeed, the deep pathway and the long residence time of the plumbing system acts to smooth out short-term (decadal-scale) variations in recharge $\delta^{18} \mathrm{O}$. This is, however, compensated for by the presence of U-rich speleothems free of a detrital component. Although the source of the $U$ is still unclear, it is possible to claim that these positive characteristics of Corchia cave are certainly due to its particular geomorphological and geological evolution, which can be summarized as follows:

1) A relatively old cave developed over different altitudes during the progressive uplift of the chain, probably in condition of drainage very different than present allowing the development of very large and deep passages;

2) Dewatering phases that have left the deepest chambers well away from clastic input and with long drip pathways;

3) Peculiar geological situation that has permitted the water to intercept and dissolve a significant source of $U$ that facilitates radiometric dating;

4) In the last $1 \mathrm{Ma}$ at least, no significant changes have occurred in the relief and in the epikarst in a way that speleothems have grown in very similar conditions.

The conditions discussed above seem to approach the case of the qualitative models proposed by Fairchild et al. (2007), and can explain the relationships between the geomorphic condition (i.e. flow path) and speleothem properties (e.g. fabrics and chemistry), which can be found in some deep caves, as the Corchia case.

The size of the cave and the amount of speleothem material collected so far (plus two recent flowstone drilling campaigns which have produced more than $8 \mathrm{~m}$ of core) indicate we are only at the beginning of exploring this exceptional archive of past climate, the protection of which is as important as the discovery of its own geological secrets.

\section{ACKNOWLEDGEMENTS}

We are indebt with Federazione Speleologica Toscana for its support during the last ten years and for funding this research. We must also thank the President of the Parco delle Apuane (G. Nardini) and the Director (Dr. A. Bartelletti), G. Ledda, G. Bruschi, L. De Cesari,
F. Malfatti, and the Gruppo Speleologico Lucchese for their friendships and help during fieldwork. We thank Kathleen R. Johnson for the revision of the first draft of the manuscript.

\section{APPENDIX (MATERIAL AND METHODS)}

The tourist cave has been monitored since 1996 following a precise request of the Federazione Speleologica Toscana in order to assess the impact of tourist activity on the cave environment. This duty was entrusted to the Regional Agency of the Environment (ARPAT) which selected three sites for continuous monitoring (after preliminary analyses) of temperature, $\mathrm{CO}_{2}$ concentration, air movement (velocity), and humidity. The $\mathrm{CO}_{2}$ concentration monitoring system suffered several problems of calibration, and past measurements are not considered completely reliable and are not discussed here. The three sites were selected as representative of conditions near the cave entrance (station 1), intermediate conditions (station 2) and very stable deep interior conditions (station 3, "Galleria delle Stalattiti"). Since 2002, two meteorological stations were set up outside the cave (principally for measures of temperature, wind speed, and rainfall amount). Collection of the data were sufficient for describing the general pattern of the measured parameters but the period of maintenance and the problems related to the cut off of power produced gaps in the data records. During the activity for preparation of the tourist cave and after the opening, the water chemistry of running and drip waters has been sporadically collected in several places along the tourist passage. Since this time, the Istituto di Geoscienze e Georisorse-CNR (national research council) of Pisa and the Earth Science Department of the University of Pisa installed two stations (CNR1 and CNR2) for collecting drip waters for stable isotope and chemical analyses. Sampling was conducted irregularly since 2003 up to the present. Since 1997, a system for the collection and measurement of rainfall amount was established at the so-called Southwest nose (1074 $\mathrm{m}$ a.s.1.) near the cave entrance of Buca del Serpente (Fig. $544^{\circ} 01^{\prime} 27^{\prime \prime}$ nord; $10^{\circ} 18^{\prime} 05^{\prime \prime}$ est). Water collection is usually every three months, according to local weather conditions. These samples were considered suitable only for chemical analyses and a new station for collection of rainfall samples for stable isotope is now in progress, even if local isotopic composition of meteoric water is reasonably well known (e.g. Mussi et al., 1998).

This large amount of data is now being organised into a Geographical Information System based at the Istituto Nazionale di Geofisica e Vulcanologia (INGV) of Pisa.

Chemical analysis have been carried out at the ARPAT laboratory of Florence, for the major constituents atomic absorbing spectrometry (AAS) has been used, whereas for trace elements the AAS-GF and ICP-MS have been used. Mantelli et al. (2002) have discussed methodologies and analytical performances.

The oxygen isotope composition of waters was obtained by the equilibration of water with $\mathrm{CO}_{2}$ at 
$25^{\circ} \mathrm{C}$ (Epstein and Mayeda, 1953), while the isotopic composition of hydrogen was carried out following a modification of the procedure proposed by Coleman et al. (1982), which consists of reducing water to $\mathrm{H}_{2}$ using metallic zinc. The carbon isotope composition of dissolved inorganic carbon (DIC) were obtained measuring the $\mathrm{CO}_{2}$ exsolved by water by progressive adding an excess of $\mathrm{H}_{3} \mathrm{PO}_{4}$ followed by the $\mathrm{CO}_{2}$ extraction and purification using cryogenic traps under vacuum. The ${ }^{18} \mathrm{O} /{ }^{16} \mathrm{O},{ }^{2} \mathrm{H} / \mathrm{H}$ and ${ }^{13} \mathrm{C} /{ }^{12} \mathrm{C}$ ratios were measured using a Finnigan MAT 250 and a Micromas $602 \mathrm{C}$. The results are expressed using the well-known $8 \%$-notation with respect to $\mathrm{V}$-SMOW, whereas ${ }^{13} \mathrm{C} /{ }^{12} \mathrm{C}$ ratios are expressed respect to the V-PDB standard. Analytical precision was $\pm 0.1, \pm 1$ and $\leq \pm$ $0.3 \%$ for oxygen, hydrogen and carbon respectively. Determination of tritium content was done by means of $\beta$ - counting of the gaseous phase, with a "Beta Logic" proportional counter, using ethane obtained by reaction of hydrogen with ethylene in excess of $8 \%$. The concentration is expressed in tritium TU units; the analytical precision is around $1-2 \%$ for the tritium content analysed in the Corchia samples.

\section{REFERENCES}

Abbate E., Balestrieri M.L., Bigazzi G., Norelli, P. \& Quercioli C., 1994 - Fission-track datings and recent rapid denudation in Northen Apennines, Italy. Memorie Società Geologica Italiana, 48: 579-585.

Badino G., 2004 - Cave temperatures and global climate change. International Journal of Speleology, 33 (1/4), 103-114.

Balestrieri M.L., Bernet M., Brandon M.T., Picotti V., Reiners P. \& Zattin M., 2003 - Pliocene and Pleistocene exhumation of two key areas of the Northern Apennines. Quaternary International, 101102: 67-73.

Bartolini C., 2003 - When did the Northern Apennine become a mountain chain? Quaternary International, 101-102: 75-80.

Braschi S., Del Freo P. \& Trevisan L., 1986 Ricostruzione degli antichi ghiacciai sulle Alpi Apuane. Atti Società Toscana di Scienze Naturali, Mem., s. A , 93: 203- 219.

Calistri M., 1974 - Studi di geomorfologia e neotettonica: II - Il Pliocene fluvio-lacustre della conca di Barga. Memorie Società Geologica Italiana, 13: 1-22.

Carmignani L. \& Giglia G., 1983 - Il problema della doppia vergenza sulle Alpi Apuane e la struttura del Monte Corchia. Memorie Società Geologica Italiana, 26: 515-525.

Carmignani L. \& Kligfield R, 1990 - Crustal extension in the Northern Apennines: the transition from compression to extension in the Alpi Apuane Core Complex. Tectonics, 9(6): 1275-1303.

Clark I. \& Fritz P., 1997 - Environmental Isotopes In Hydrogeology. Lewis Publishers, CRC Press, Boca Raton - New York, pp. 328.

Coleman M.L., Shepherd T.J., Durham J.J., Rous J.E. \& Moore G.R., 1982 - Reduction of water with Zinc for Hydrogen isotope analysis. Analytical Chemistry, 54: 993-995.
Cortecci G., Dinelli E., Molli G. \& Ottria G., 2003 Geochemical evidence for fluid-rock interaction along high angle faults in the Alpi Apuane, NW Tuscany, Italy. Periodico di Mineralogia, 72: 35-47.

Doveri M., Leone G., Mussi M. \& Zanchetta G., 2005. Composizione isotopica di acque ipogee nell'Antro del Corchia (Alpi Apuane, Toscana nord-occidentale). Memorie Istituto Italiano di Speleologia, S. II, 18: 119-132.

Drysdale R., Zanchetta G., Hellstrom J.C., Fallick A.E., Zhao J.X., Isola I. \& Bruschi G., 2004 - Palaeoclimatic implications of the growth history and stable isotope $\left(\delta^{18} \mathrm{O}\right.$ and $\left.\delta^{13} \mathrm{C}\right)$ geochemistry of a Middle to Late Pleistocene stalagmite from central-western Italy. Earth and Planetary Science Letters, 227: 215-229.

Drysdale R., Zanchetta G., Hellstrom J., Fallick A. \& Zhao J.X., 2005 - Stalagmite evidence for the onset of the Last Interglacial in southern Europe at $129 \pm$ 1 ka. Geophysical Research Letters, 32, L24708, doi:10.1029/ 2005GL024658.

Drysdale R., Zanchetta G., Hellstrom J., Fallick A., McDonald J. \& Cartwright I., 2007 - Stalagmite evidence for the precise timing of North Atlantic cold events during the early last glacial. Geology, 35: 7780.

Dulinski M. \& Rozanski K., 1990 - Formation of ${ }^{13} \mathrm{C} /{ }^{12} \mathrm{C}$ isotope ratios in speleothems: a semi-dynamic model. Radiocarbon, 32: 7-16.

Elter P., 1975 - Introduction à la géologie de l'Apennin septentrional. Bulletin de la Société géologique de France, 7: 956-962.

Epstein S., Mayeda T., 1953 - Variation of $O^{18}$ content of waters from natural sources. Geochimica Cosmochimica Acta, 4: 213-224.

Fairchild I.J., Borsato A., Tooth A.F., Frisia S., Hawkesworth C.J., Huang Y., McDermott F. \& Spiro B., 2000 - Controls on trace element (Sr-Mg) compositions of carbonate cave waters: Implications for speleothem climate records. Chemical Geology, 166: 255-269.

Fairchild I.J., Frisia S., Borsato A. \& Tooth A.E., 2007 - Speleothems. In: Nash D.J. \& McLaren S.J. (Eds): Geochemical Sediments and Landscape, Blackwell, Oxford, 200-245

Fellin M.G., Reiner P.W., Brandon M.T., Molli G., Balestrieri M.L. \& Zattin M., 2004 - Exhumation of the Northern Apennines core: new thermochronological data from the Alpi Apuane. 32th International Geological Congress Florence, Italy, August 20-28, Abstract: 297-299.

Fellin M.G., Reiner P.W., Brandon M.T., Balestrieri M.L. \& Molli, G., 2007 - Exhumation of the Northern Apennines core: new thermochronological data from the Alpi Apuane. Tectonics, 26, in press.

Franceschelli M., Pusceddu M., Carcangiu G., Gattiglio M. \& Pannuti F., 1996 - Breccia-hosted manganeserich minerals of Alpi Apuane, Italy: A marine, redoxgenerated deposit. Lithos, 37: 309-333.

Gat J.R. \& Carmi I., 1970 - Evolution of the isotopic composition ofatmosphericwaters in the Mediterranean area. Journal of Geophysical Research, 75: 30393048. 
Hendy C.H., 1971 - The isotopic geochemistry of speleothems $-I$. The calculation of the effect of different modes of formation on the isotopic composition of speleothems and their applicability as palaeoclimatic indicators. Geochimica Cosmochimica Acta, 219: 807-824.

Hellstrom J., 2007 - U-Th dating of speleothems with high initial ${ }^{230} \mathrm{Th}$ using stratigraphical constraint. Quaternary Geochronology, 1: 289-295.

Hoefs J., 2004 - Stable Isotope Geochemistry. Springer, Berlin-Heidelberg-New York, pp. 244.

Kligfield R., Hunziker J., Dallmeyer RD. \& Schamel S., 1986 - Dating of deformational phases using $\mathrm{K}-\mathrm{Ar}$ and ${ }^{40} \mathrm{Ar} /{ }^{39} \mathrm{Ar}$ techiniques: results from the Northern Apennines. Journal of Structural Geology, 8: 781-798.

Laurenzi M.A., Tucci P., Turi B., 1982 -Considerazioni geotermometriche sulle formazioni metamorfiche di età meso-cenozoiche del settore del M. Corchia. Periodico di Mineralogia, 52: 189-204.

Longinelli A. \& Selmo E., 2003 - Isotopic composition of precipitation in Italy: a first overall map. Journal of Hydrology, 270: 75-88.

Lotti B., 1881 - Nota sopra una piega con rovesciamento degli strati paleozoici e triassicci fra il Monte Corchia e la Pania della Croce presso Mosceta. Bollettino del Regio Comitato Geologico Italiano, 12: 85-96.

Mantelli F., Montigiani A., Bianucci P.L., Lotti L. \& De Sio F., 2001 - Stato di qualità delle acque durante la fase ante-operam del settore dell'Antro del Corchia destinato a fruizione turistica. Atti $\mathrm{VII}^{\circ}$ Congresso della Federazione Speleologica Toscana, Gavorrano: 13-22.

Mantelli F., Luchetti G., Montigiani A., Lotti L. \& De Sio F., 2003 - Lo stato delle acque dell'Antro del Corchia in relazione alla vulnerabilità degli acquiferi carsici. Atti del Convegno "Le risorse idriche sotterranee delle Alpi Apuane: conoscenze attuali e prospettive di utilizzo". Forno, Massa: 105-117.

Mantelli F., Piccini L., Montigiani A., Cecconi E. \& Lotti L. 2005 - Geochimica delle acque di circolazione nel Complesso Carsico del Monte Corchia. Memorie Istituto Italiano di Speleologia. S. II, 18: 177-189.

Mavlyudov B., 1997 - Caves climatic systems. Proc. 12th International Congress of Speleology, vol. 1. La Chaux-de-Fonds, Switzerland: 191-194.

Maxwell J.C., 1956 - Tectonics of Pania della CrocePania Secca area, Alpi Apuane. Bollettino Società Geologica Italiana, 75: 55-79.

McDermott F., Schwarcz H. \& Rowe P.J., 2005 - Isotopes in speleothems. In: Leng M.J. (Ed): Isotopes in Palaeoenvironmetal Research. Sprinter, Netherland: 185-225.

Molli G. \& Meccheri M., 2000 - Geometrie di deformazione nell'alta valle di Colonnata: un esempio di deformazione polifasica e composita nelle Alpi Apuane. Bollettino Società Geologica Italiana, 119: 379-394.

Molli G. \& Vaselli L., 2006 - Structures, interference patterns, and strain regimes during midcrustal deformation in the Alpi Apuane (Northern Apennines Italy). Geological Society of America, Spec. Pub. 414: 79-93.
Mussi M., Leone G. \& Nardi I., 1998 - Isotopic geochemistry of natural waters from the Alpi Apuane-Garfagnana area, Northern Tuscany, Italy. Mineralogica Petrographica Acta, 41: 163-178.

Ottria G. \& Molli G., 2000 - Superimposed brittle structures in the late orogenic extension of the Northern Apennine: results from Carrara area (Alpi Apuane, NW Tuscany). Terra Nova, 12(2): 1-8.

Piccini L., 1991 - Ipotesi sulla origine e sulla evoluzione del Complesso Carsico del Monte Corchia. Atti $\mathrm{VI}^{\circ}$ Congr. Federazione Speleologica Toscana, Stazzema (Lucca): 59-82.

Piccini L., 1994 - Caratteri morfologici ed evoluzione dei fenomeni carsici profondi nelle Alpi Apuane (Toscana - Italia). Natura Bresciana, Annali del Museo Civico di Scienze Naturali Brescia, 30 (1996): 45-85.

Piccini L., 1998 - Evolution of karst in the Alpi Apuane (Italy): Relationships with the morphotectonic history. Suppl. Geografia Fisica e Dinamica Quaternaria, 3(4) : 21-31.

Piccini L., 2002 - Acquiferi carbonatici e sorgenti carsiche delle Alpi Apuane. Atti Conv. "Le risorse idriche sotterranee dele Alpi Apuane: conoscenze attuali e prospettive di utilizzo", Forno (Massa): 41-76.

Piccini L., Pranzini G., Tedici L. \& Forti P., 1999 - Le risorse idriche dei complessi carbonatici del comprensorio Apuo-Versiliese. Quaderni di geologia Applicata, 6(1): 61-78.

Piccini L., Drysdale R. \& Heijnis H., 2003 - Karst caves morphology and sediments as indicators of the uplift history in the Alpi Apuane (Tuscany, Italy). Quaternary International, 101-102: 219-227.

Quiros Castillo J.A. (ed.) 2004 - Archeologia e storia di un castello Apuano. Gorfigliano dal medioevo all'età moderna. Biblioteca del Dipartimento di Archeologia e storia delle Arti, Università di Siena, Insegna del Giglio, Firenze, 332 pp.

Rapetti F. \& Vittorini S., 1994 - Carta climatica della Toscana centro-settentrionale. Pacini Editore, Pisa.

Roncioni A., 2002 - La Federazione Speleologica Toscana e le ricerche idrologiche nelle cavità carsiche delle Alpi Apuane. Atti Conv. "Le risorse idriche sotterranee dele Alpi Apuane: conoscenze attuali e prospettive di utilizzo", Forno (Massa): 77-104.

Rozanski K., Araguàs-Araguàs L., Gonfantini R., 1993 - Isotopic patterns in modern global precipitation. In: Swart P.K., Lohmann K.C., McKenzie J., Savin S. (eds): Climate change in continental isotopic records. Geophysical Monograph 78. American GeophysicalUnion: 1-36.

Spötl C. \& Mangini A., 2007 - Speleothems and paleoglaciers. Earth and Planetary Science Letters 254: 323-331

Woodhead J., Hellstrom J., Maas R., Drysdale R., Zanchetta G., Devine P. \& Taylor E., 2006 $U-P b$ geochronology of speleothems by MC-ICPMS. Quaternary Geochronology 1: 208-221

Zaccagna D., 1932 - Descrizione Geologica delle Alpi Apuane. Mem. Descr. Carta Geologica d'Italia, 25: 1-440. 
Zanchetta G., Drysdale R.N., Hellstrom J., Fallick A.E., Isola I., Bruschi G. \& Roncioni A., 2005. L'archivio climatico preservato all'interno delle stalagmiti dell'Antro del Corchia (Alpi Apuane, Italia Centrale): $i$ dati isotopici. Memorie Istituto Italiano Speleologia, S. II, 18, 161-176.
Zanchetta G., Drysdale R.N., Hellstrom J.C., Fallick A.E., Isola I., Gagan M.K., Pareschi M.T., 2007-Enhanced rainfall in the Western Mediterranean during deposition of sapropel S1: stalagmite evidence from Corchia cave (Central Italy). Quaternary Science Reviews, 26: 279-286. 